A thematic paper supporting the OECD DAC INCAF project

'Global Factors Influencing the Risk of Conflict and Fragility'

\title{
International markets for security and military assistance
}

Roy Isbister and Tom Donnelly

Saferworld

OECD DEVELOPMENT CO-OPERATION

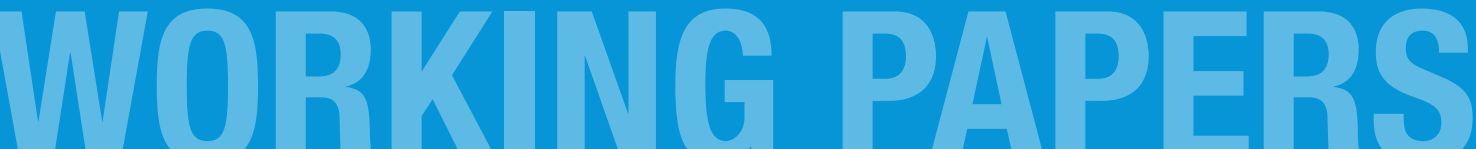

The Development Assistance Committee: Enabling effective development 
This work is published on the responsibility of the Secretary-General of the Organisation for Economic Cooperation and Development (OECD). The opinions expressed and arguments employed herein do not necessarily reflect the official views of the Organisation or of the governments of its member countries.

This document and any map included herein are without prejudice to the status of or sovereignty over any territory, to the delimitation of international frontiers and boundaries and to the name of any territory, city or area.

\section{Note to the reader}

This paper is one of eight thematic papers supporting the OECD DAC INCAF project on Global Factors Influencing the Risk of Conflict and Fragility. Each paper explores a specific global factor. The synthesis report, Think Global, Act Global: Confronting global factors influencing conflict and fragility (OECD, 2012), can be found at:

\section{www.oecd.org/dac/conflictandfragility/globalfactors.htm}

While the thematic papers have been subjected to a robust peer review process, they remain working papers rather than for publication in peer-reviewed journals. 


\begin{abstract}
The end of the Cold War, globalisation, and the new global security paradigm following the 9/11 attacks have seen a rapid increase in arms production and producers across different geographic regions, as well as the growth of private security enterprises in areas that were previously primarily state-controlled. This paper explores the key dimensions of international markets in military and security assistance including conventional weapons and ammunition, related services such as training and maintenance and the provision of personnel and other services via private military and security companies. These are particularly relevant to fragile and conflict-affected contexts given the demand that emanates from these contexts for the equipment and services international markets in military and security assistance offer.
\end{abstract}

The paper outlines how at best, international markets in military and security assistance can help state security services to provide responsive and accountable services to their populations. At worst, they can provide the tools, know-how and people to commit human rights violations and other crimes. Other aspects of this market also potentially affect state legitimacy, in particular the massive levels of corruption associated with the international arms trade. The paper suggests some entry points for the international community to mitigate the potential risks posed by international markets in mil/sec assistance to conflict and fragility, beginning with options for developing and consolidating the existing regulatory frameworks, linking controls on markets for equipment and services and then broadening out to link with other issue areas such as governance, peacebuilding and statebuilding. 


\section{Table of Contents}

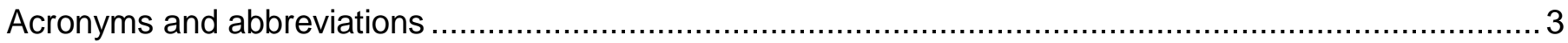

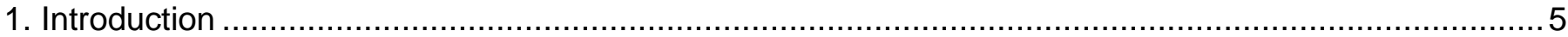

2. Why do international markets in military and security assistance matter for conflict and fragility? $\ldots \ldots \ldots . . .7$

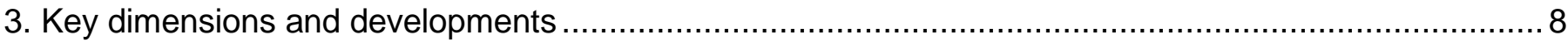

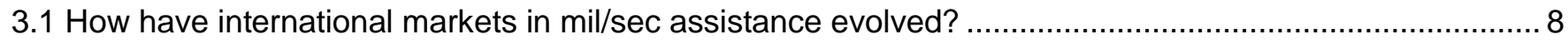

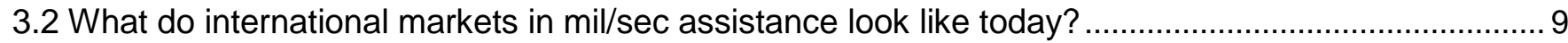

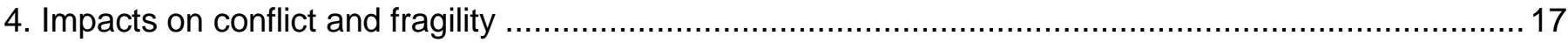

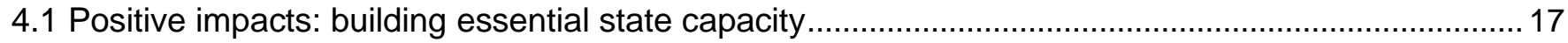

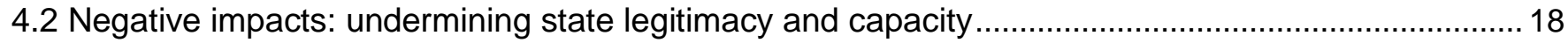

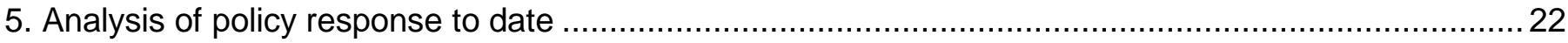

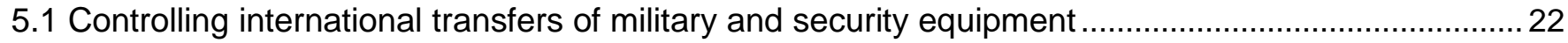

5.2 Controlling international markets in security and military services ……............................................ 26

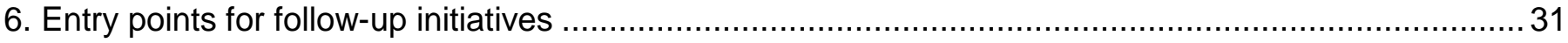

6.1 Entry point 1: Expanding and consolidating international and regional regulatory frameworks.......... 31

6.2 Entry point II: Regulating military and security assistance at both source and destination .................. 31

6.3 Entry point III: Linking access to markets in military and security assistance to good governance ... 32

6.4 Entry point IV: Developing guidelines for PMSCs for supporting security and justice programming. 32

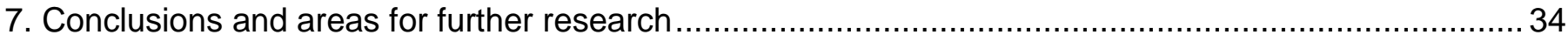

7.1 How can embargoes/sanctions regimes be more effective? ................................................................ 34

7.2 How can the regulation of military and security assistance be improved in areas of weak or disputed

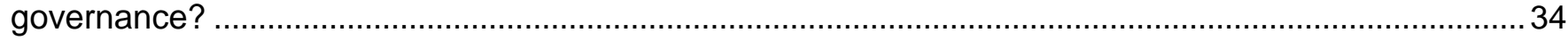

7.3 What best practice in import controls can we apply?

7.4 How can we trace illicit conflict ammunition?

7.5 Are current guidelines on the use of private security providers in humanitarian and development

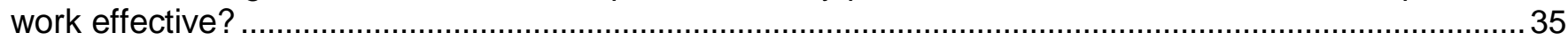

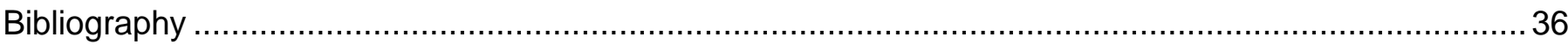

\section{Boxes}

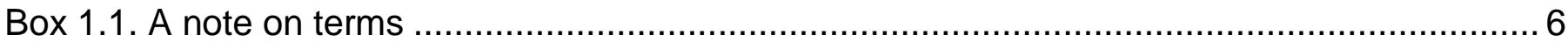

Box 3.1. Post-Cold War arms supplies from Eastern Europe …......................................... 8

Box 3.2. High-tech, high-cost production: The F-35 Joint Strike Fighter ................................. 11

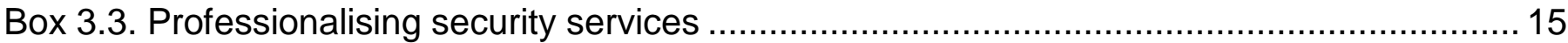




\section{Acronyms and abbreviations}

$\begin{array}{ll}\text { AU } & \text { African Union } \\ \text { ECOWAS } & \text { Economic Community of West African States } \\ \text { EISF } & \text { European Interagency Security Forum } \\ \text { FCAS } & \text { Fragile and conflict-affected states } \\ \text { ICOC } & \text { International Code of Conduct for Private Security Providers } \\ \text { IMO } & \text { International Maritime Organisation } \\ \text { ISOA } & \text { International Stability Operations Association } \\ \text { NATO } & \text { North Atlantic Treaty Organisation } \\ \text { NSAG } & \text { Non-state armed groups } \\ \text { OSCE } & \text { Organisation for Security and Co-operation in Europe } \\ \text { PMSC } & \text { Private military and security companies } \\ \text { PSC } & \text { Private security company } \\ \text { PSP } & \text { Private security providers } \\ \text { SALW } & \text { Small arms and light weapons } \\ \text { SIPRI } & \text { Stockholm International Peace Research Institute } \\ \text { TFG } & \text { Transitional Federal Government (Somalia) } \\ \text { WTO } & \text { World Trade Organization }\end{array}$




\section{Introduction}

The end of the Cold War saw the demise of a well-established international order. However, hopes for a calmer, less-dangerous world soon ebbed; with the loosening of the familiar geostrategic and ideological straightjacket, and without the superpowers working to bend the dynamics of any situation to their own logic, local conflicts and tensions began to accelerate. Intra-state conflict has become more common than inter-state conflict. Western powers have struggled to come to terms with the notion that no longer is there one easily-identifiable foe, but instead a proliferation of smaller, less-easily-understood threats to their perceived interests. ${ }^{1}$

Major changes to the international system have been accompanied by significant changes in the way security and military assistance is provided, demanded and used. The scope of goods and services covered by international markets for military and security assistance is broad (Box 1.1). It includes conventional weapons and ammunition, related services such as training and maintenance and the provision of personnel via private military and security companies.

The regulatory landscape for supplying equipment has in many cases been tightened and transformed nationally and regionally, and to a lesser extent globally. Yet for the most part, states - and also determined, reasonably-resourced non-state groups operating in fragile and/or conflict-affected environments - are still able to satisfy their demands for conventional arms or security equipment. Regulatory gaps and loopholes, whether geographic or related to certain types of actors or activity, are still all too common, while some actors - state and non-state - seem willing to ignore regulations or interpret them inconsistently when they consider it in their economic or strategic interests to do so. In fragile and conflict-affected states (FCAS, see Box 1.1 for definitions), the consequences of this behaviour can be devastating.

Despite their weaknesses, however, formal systems do exist to control the movement of arms and other military equipment (Section 5). The same cannot be said of the services provided by private military/security companies. Formal controls over such groups are considerably less developed, in part because the market itself is more immature, particularly in FCAS. In the past 10-15 years there has been a trend towards transferring to the private sector activities which would have routinely been handled by state forces until very recently. Examples include actual combat, close protection of diplomatic staff, perimeter security of state and commercial facilities, convoy security, prison management, and the training of military and security personnel. The recent surge in international piracy has created yet another market for private security providers in the form of merchant vessel protection. Yet this expansion of the scale and scope of activities delivered by private military and security companies (PMSCs) has not so far been matched by an expansion in state control and regulation: the same "supplier" states that have done most to promote state control over international markets in military equipment have seemed satisfied with selfregulation for PMSCs.

\footnotetext{
${ }^{1}$ Then CIA Director James Woolsey is quoted as telling Congress in 1993 that "We have slain a large dragon. But we live now in a jungle filled with a bewildering variety of poisonous snakes." See, for instance: www.cia.gov/library/center-for-the-study-ofintelligence/csi-publications/books-and-monographs/directors-of-central-intelligence-as-leaders-of-the-u-s-intelligencecommunity/chapter 12.htm\# ftn1.
} 


\section{Box 1.1. A note on terms}

A great deal of debate on the private sector's provision of security services revolves around the issue of terminology: what exactly is a private military and security company, a private security provider, a mercenary or any number of other nomenclatures. While this may have significant legal consequences in terms of industry regulation, there is no need in this paper to provide precise definitions. Instead, we take a very broad approach to the provision of services within "international markets for security and military assistance" and use a variety of terms for the groups involved (usually whichever is used by the piece of research or other source being discussed).

We define a "fragile state" (FCAS) as one which has weak capacity to carry out basic functions of governing a population and its territory, and which lacks the ability to develop mutually constructive and reinforcing relations with society. This definition is drawn from the OECD-DAC Guidelines on Supporting Statebuilding in Situations of Conflict and Fragility (OECD, 2011).

This paper explores the key dimensions of international markets in military and security assistance (mil/sec assistance for short) in the context of broader international developments over the last 20 years. It considers some of the positive and negative impacts of international markets in mil/sec assistance on the risk of conflict and fragility and offers a brief analysis of current policy responses. The paper then suggests some entry points for the international community to mitigate the potential risks posed and identifies possible areas for future research. 


\section{Why do international markets in military and security assistance matter for conflict and fragility?}

The provision of security and military goods and services is almost by definition fundamental to how states and other groups understand and experience peace, conflict and security. The supply (or lack) of conventional weapons, expertise and capacity has a major impact on the way that people plan and behave. Depending on what is available and how they are used, they can either reduce or fuel conflict and fragility; and can either support or undermine good governance, peace and security.

Effective and legitimate states need to deliver basic public goods and services to their populations, exercise control over their national territories and develop constructive relations with society. Central to this is the right and responsibility to secure their citizens from external and internal threats and to produce or procure the necessary equipment and capacity to do so. States that are unable to deliver such basic public goods - either through a lack of capacity or will or because their ability to do so is contested by alternative sources of power - are likely to suffer from a lack of legitimacy and be more vulnerable to the risk of violent conflict. This link between capacity and legitimacy is central to OECD and World Bank definitions of "fragility" (Box 1.1) and a fundamental element in the relationship between fragility and violent conflict.

Two key elements of capacity are equipment and specialist skills, and most states rely on international markets to source one or both of these. Whilst the ability or otherwise to acquire mil/sec assistance would seldom be regarded as a structural driver of conflict, irresponsible or unregulated supply and use of $\mathrm{mil} / \mathrm{sec}$ assistance certainly acts as an exacerbating factor, which increases (1) the likelihood that a conflict will turn violent; (2) the lethality and intensity of conflict once the threshold into violence is crossed; and (3) the risk of a return to violence after a conflict.

Similarly, the trend towards private mil/sec assistance raises questions about legitimacy. The growing use of PMSCs to supplement or replace state capacity in security service provision challenges the traditional notion of state monopoly on the use of force and poses significant questions for state legitimacy and accountability, particularly in FCAS. For both goods and services, more work is needed to ensure international markets function to support rather than undermine development and peace and statebuilding efforts in FCAS. The following section gives an overview of the key dimensions and developments in these markets. 


\section{Key dimensions and developments}

\subsection{How have international markets in mil/sec assistance evolved?}

The nature of international markets in mil/sec assistance since the Cold War has changed in response to shifts in the world more broadly, both as they directly relate to security and conflict (and fragility), but also in terms of more general economic and financial trends. While some of these have generic application, others relate more directly to circumstances prominent in FCAS.

\section{Products}

Whereas formerly the range of suppliers of security and military equipment was limited, the base of supply has broadened significantly in the last 20 years. During the Cold War, state ownership of the means of production, sale and movement of military and security goods was common, while cross-border coproduction was relatively rare (and only among allies when it did occur). Since then, the arms industry has been subject to the same trends as other sectors: privatisation, increasing specialisation, offshore sourcing and cross-border co-operation. This has however been mitigated by governments' concerns about the potential strategic risks involved in sourcing the means of defence from elsewhere (even though all states now do this to a varying degree and most have always done so) and in letting domestic industry sell certain goods to certain international actors. The number of states involved in arms production has been increasing, in part because of the dynamics of specialisation and so on mentioned above, but also because more states have taken an active decision to want to develop this industrial sector. In some instances this has traditionally been seen as a way of jump-starting broader industrialisation.

There has also been a specialisation and diversification of roles within the transfer process, for example in transportation, which parallels the broader developments in moving all kinds of cargo around the world. There is even an additional specialist niche in the case of mil/sec assistance: certain operators (brokers and transporters) who will arrange and deliver high-risk shipments of critical items, e.g. arms, into and around FCAS.

The activities of these specialist brokers and transporters were given a major boost in the early 1990s with the end of the Cold War. A range of factors in several ex-Warsaw Pact states created a new source of supply. These included the weakness of central authority to exert control; overcapacity of military production; the existence of large, poorly-secured stockpiles (especially of small arms, light weapons and ammunition); the availability of large cargo aircraft; and the demobilisation of significant numbers of military and intelligence officials, some of whom had the right contacts and few scruples. ${ }^{i}$ This supply perfectly met the demand for lower-end military equipment from less developed countries that were experiencing internal hostilities, aided by the absence of external discipline that had been maintained by the Cold War super-powers and blocs. While it was always likely that networks would be organised to meet demand, and indeed specialist arms brokers existed before 1990, the conditions in Eastern Europe gave this development a kick-start, and established patterns of supply that are still relevant today (Box 3.1).

Box 3.1. Post-Cold War arms supplies from Eastern Europe

Soon after the Cold War ended, Bulgaria began exporting large quantities of surplus weapons, many to countries affected by conflict. These included the export of 62 tanks to separatist forces in southern Yemen, and 140 tanks to Ethiopia and Uganda in 1998 (Saferworld, 2002). Bulgaria exported 24 T-62 tanks and 29 armoured combat vehicles to Angola in 1993, while a 2000 UN Panel of Experts report stated that "the evidence collected as a result of the Panel's own investigations overwhelmingly points towards Bulgaria as the source of origin for the majority of the arms purchased by UNITA—at least since 1997" (UN Security Council, 2000). 


\section{Services}

Turning to the private provision of military and security services, at the end of the Cold War this type of activity was very limited, and indeed regarded with deep suspicion. This followed on from the post-World War II decolonisation period, during which the role of "mercenaries" was largely discredited. The 1989 International Convention against the Recruitment, Use, Financing and Training of Mercenaries (UN General Assembly, 1989) can be seen as one manifestation of this phenomenon, although many key states have never ratified this convention (ICRC, n.d.). Furthermore, the evolving use of terms such as "private military" and "private security companies" seems to have created a new space for activities that would once have been labelled as "mercenary".

As with military goods, the end of the Cold War catalysed the first major shift in the market by creating a new source of supply for mil/sec services. The demobilisation of personnel in the old Eastern bloc released a large number of people onto the market who had extremely specific skills, expertise and contacts.

The market then underwent a second shift in the last decade or so, triggered by the 9/11 attacks on the United States. The "long war" that began in response to 9/11 has played out in foreign lands, particularly in Afghanistan and Iraq. In these two countries, NATO and the wider Western alliance of states found PMSCs to be indispensable for delivering ambitious military and strategic objectives. Moreover, the relative lack of enthusiasm for these conflicts among the general public of these states has made the issue of troop casualties particularly politically sensitive. Many of these states have thus sought to lower the profile and limit the role of state actors by transferring responsibility to private actors: PMSCs provide a mechanism which can sidestep some of the domestic political challenges that come with the deployment of troops and other state actors.

Another effect of 9/11 was to raise the prominence of the discourse on the impact of fragile states on international peace and security. There is concern that FCAS allow the existence of "ungoverned spaces" where groups that are perceived as a threat - such as al-Qaeda affiliates, transnational criminal networks and pirates - can operate freely. In recent years, there has been a gradual convergence between these security concerns and the recognition among development and humanitarian actors that FCAS are home to many of the world's poorest people and a disproportionate number of major humanitarian disasters.

Hence, both security and development bodies have increasing interests in FCAS (sometimes in cooperation, but often in parallel). Yet at the same time, domestic trends have seen Western states contracting out key state functions to external providers. Hence, an increasing proportion of international organisations' operations in FCAS are actually carried out by other groups - including PMSCs - from delivering security-related training to providing protection for development workers (discussed further below).

\subsection{What do international markets in mil/sec assistance look like today?}

There are some significant differences between the operation and regulation of international markets for $\mathrm{mil} / \mathrm{sec}$ equipment and those for mil/sec services. For equipment, the dominant model is for production to be the complete preserve of commercial companies, but for no actual transfers to take place without the express permission of the government with jurisdiction over the export. By contrast, many of the services undertaken by private security contractors are provided without express governmental permission. These differences reflect the fact that the regulatory framework for arms transfers is more mature than for military and security services (see Section 5), but also that it is much easier for states to control activities within their own borders than in another country. 


\section{Products}

While the idea that defence manufacturers can (and perhaps should) be privately-owned companies has penetrated widely. The international market for military and security equipment transfer is not a "normal" market; there is a range of factors unique to the sector that either promotes production and trade or restricts supply.

Firstly, the political and strategic value placed on defence and security provision encourages states to develop and sustain a domestic defence industry even though a purely economic analysis would suggest that this does not make sense.i For the industry to keep functioning under such circumstances, governments have to take "special measures". These can include subsidising research and development programmes; purchasing domestically, even where imports offer better value; providing export credit guarantees; or offering inducements to potential purchasers in export markets. These inducements could include loan forgiveness, deferred payment options, discounted purchase prices, the use of offsets, ,ii $^{\circ}$ even arms transfers as gifts. ${ }^{\text {iv }}$ In recognition of this perceived non-economic value of arms exports, normal World Trade Organization prohibitions on non-competitive behaviour do not apply to this sector." These pressures may also go some way to explaining why the trade in military and security equipment is, reputedly, among the most corrupt. ${ }^{\mathrm{vi}}$

Developing states sometimes see defence purchases as a way of kick-starting industrial development. In part, this is because of the defence industry exception to the general WTO prohibition on offsets, which gives it leverage not available to other sectors. Combined with a longstanding and widespread belief that local defence production provides wider (civilian) commercial benefits, this promotes defence imports and local production beyond that which a "normal" market might recommend. However, while this idea of trickle-down from defence to civil might once have been true, for decades technology transfer between military and civilian sectors has been much more two-way, with the consumer electronics sector, for example, typically proving much more agile than "defence" companies at bringing innovative products to market in both the defence and civilian markets (Brzoska, 2006; Stowsky, 1991).

At the same time, as a manifestation of the principle that states should have a monopoly on the use of force, and to prevent arms transfers that are inconsistent with foreign policy and strategic goals, both exporting and importing states can be expected to place limits on possible end-users. This is less the case for small arms and their ammunition, but typically even here transfers will need official authorisation and different states have different rules on domestic possession (Section 5). The range of customers tends to become more limited as the items in question become more complex, more destructive and more expensive. For example, while some types of "military" vehicle might be sought by media organisations, humanitarian organisations or PMSCs operating in FCAS, virtually the only customer for fighter aircraft will be government. vii The situation for components for weapons systems is slightly different, as the production process may involve many transfers among a variety of commercial operators in more than one state, but the potential customers of the finished products will be very limited.

Nevertheless, on balance these factors tend to encourage a greater number of producers and more production than in a less idiosyncratic market. The more suppliers there are, the more complicated it is to prevent unwelcome proliferation, including into FCAS, particularly if "legitimate" demand is inadequate to soak up available supply.

Yet despite the push by states to develop their defence manufacturing capacity, major production is still concentrated relatively narrowly. According to figures from Stockholm International Peace Research Institute (SIPRI), more than $80 \%$ of total major conventional weapons transfers were sourced from just eight states between 2006 and 2010 (including all five members of the UN Security Council - the P5), while approximately 80 of the largest 100 arms-producing companies in the world have headquarters in just seven states (SIPRI, 2011). Import patterns are, by contrast, far more dispersed: the same threshold 
of $80 \%$ of total imports of major conventional weapons transfers is only reached by adding up the imports of more than 30 of the largest importing states.

This concentration of supply is most marked for high-end, finished weapons systems. The level and escalating expense of the technological and precision-management expertise required to produce such equipment, and the manufacturing lead-times involved, makes this a very difficult market to break into (Box 3.2). Very few countries host companies capable of leading-edge systems integration, which tends to involve a great deal of consultation and co-operation between government and producer, and even major second-tier producers such as France and the UK are under pressure to specialise in particular sectors because maintaining broad-spectrum capability is prohibitively expensive. This type of equipment is also very expensive to buy, and at least some of the technology contained in top-line systems will be jealously guarded. Because of all these limitations, this type of production will typically be irrelevant to FCAS.

Box 3.2. High-tech, high-cost production: The F-35 Joint Strike Fighter

The production of the F-35 Joint Strike Fighter by Lockheed Martin is an extreme example of the issues involved in high-tech weapon production. This multi-national programme is led by the US and involves several close allies. The design contract was signed in 1996; however the date when the aircraft will be deployed is still unclear. Estimates for the unit cost run as high as USD 200 million, and there have been several disagreements among the partner countries over access to software source codes that are required for future upgrades (Wolf, 2009; Defence Industry Daily, 2005).

Moving further down the supply chain, there is a rising number of states with ambitions to develop their military and security equipment production capability. There are advantages to established defence companies setting up component or machining processes in other countries. By creating a local interest in production, this can tie those countries into long-term supply relationships. Major defence companies also see advantages in locating "metal-bashing" functions in states where production is relatively cheap (e.g. due to low labour costs). What are the implications of this? While the production of components (often eventually to be exported to the country of final assembly) may in many cases be largely irrelevant to FCAS, of more concern could be the production of spare parts for equipment that might be used in situ. There is also a longer-term issue that spreading the technology and knowhow will result in greater proliferation.

Countries such as Israel and South Africa present interesting possible models of how "new" suppliers can affect the global market. Interestingly, both have been subject to particularly restrictive export practices at various times: South Africa in the form of an arms embargo during the apartheid era, while Israel's access to European arms has ebbed and flowed in response to changes in the situation in the Occupied Territories. As a consequence both determined to develop a strong indigenous industry. Israel is now a world-leading developer, producer and significant exporter of certain niche military technologies including air-to-air missiles, electronic systems, unmanned aerial vehicles, missile counter-measures and technology, anti-ballistic missile defence systems, and weapons upgrades (Offenhauer, 2008). South Africa has become a significant exporter of military vehicles, especially to other African states. For example, South Africa has reported to the UN Register of Conventional Arms the export of a total 3758 armoured combat vehicles to 49 countries, including 488 to 21 African states, some of which can be classed as FCAS (UN Register of Conventional Arms, n.d.)

The South African case highlights the problem of major conventional equipment that is less high-tech (such as South African armoured vehicles) and typically available from a wider range of sources, including states capable of new production or existing stocks available for export. In the context of FCAS, this type of equipment might be of interest to all conflict parties. While more expensive or sophisticated equipment might only be affordable to government clients, it is possibly not a realistic option for non-state groups who are either involved in conflict or victims of repression. An example would be the supplies since 2007 to 
Sudan of Mi-24 helicopter-gunships from Russia and Sukhoi-25 fighter-aircraft from Belarus (Amnesty International, 2012).

Proliferation of lower-tech items such as small arms and light weapons (SALW) - the weapons most in use in many of today's conflict-affected and fragile contexts - is especially marked and problematic. As far back as 2003, the Small Arms Survey was reporting that well over 1000 companies in around 100 states were "involved in some aspect of small arms production"-up from approximately 200 companies in around 50 countries in the 1980s-with at least 30 countries regarded as significant producers (Small Arms Survey, 2003). The required level of technology to produce most small arms is relatively low and already widely dispersed, with distribution of manufacturers spread across all regions of the world, which makes the control of small arms proliferation and misuse all the more difficult. In 2002, small arms were produced in 10 countries in sub-Saharan Africa, 11 in the Middle East, 20 in Asia-Pacific and 11 in South America (Small Arms Survey, 2003).

SALW are so ubiquitous in many FCAS that it is not only production that is a problem; older weapons from the immediate region may be recycled or reused, and large stocks of small arms from other parts of the world, not least from Eastern Europe, may also be accessed. For example, Ukraine still has huge stocks of Soviet-era assault rifles and prefers to dispose of them through sales - including to FCAS. Speaking in 2008, the then head of Ukrspetsexport (the state agency in charge of the sale and disposal of weapons and ammunition), Serhiy Bondarchuk, stated that any country was a legitimate recipient of Ukrainian arms so long as it was not subject to a UN arms embargo (Ivzhenko, 2008).

Also of critical importance to international markets for military and security equipment is the question of how the actual movement of arms is arranged. As already noted, there is now a plethora of specialised intermediaries involved in moving goods rapidly and efficiently. While there is no reason to doubt that most operators involved in such activities conduct their affairs in a legitimate manner, there are also those who are less scrupulous. Some may simply be interested in avoiding "unnecessary" bureaucracy by taking shortcuts with the paperwork, whereas others will be deliberately operating in substantive breach of the law for financial or more rarely, political reasons.

Note that such intermediaries, be they brokers, agents, transporters or freight forwarders, will typically also be involved in other trade, legal and illegal. This type of intermediary is often key in the supply of arms into FCAS, especially when accessing the equipment in the first place is legally ambiguous or clearly illegal. Where there is a high risk of being caught up in the conflict or because conditions are poor, these intermediaries may provide the cheapest or even the only means of efficient cargo transportation into the area. While intermediaries have long existed, it was once again the end of the Cold War and the break-up of the Soviet Union that delivered a sudden stock of brokers, pilots and even cargo planes who could fulfil these functions. These specialist operators are adept at organising their affairs so as to minimise the risk of being clearly identified as breaking the law.

\section{Services}

In comparison with markets for products, the provision of services is an odd combination of selective prohibition and light-touch, self or non-regulation. The activities of PMSCs have spread into more and more areas, but there are some activities that are still, in theory, strictly the preserve of governments. These include any state obligations under international humanitarian law or international human rights law, such as the processing and detainment of prisoners of war or actual combat operations. States also reserve the right to regulate the activity of private or non-state actors in the military and security fields, although how and when they choose to exercise that right varies. For example states vary in what they are prepared to tolerate within their own territory and what is considered acceptable elsewhere. One manifestation of this is that governments of the states which are the "home" of most PMSCs tend to favour self-regulation and codes of conduct, whereas governments in or near conflict-affected areas are more inclined towards legislative control. 
Demand for private military and security services comes in various forms and from various sources. Firstly, both foreign and local actors in FCAS (whether commercial, diplomatic, or non-governmental) require protective services. This can include the protection of people, facilities, infrastructure and resources, transportation, commercial and financial interests.

For example, a 2008 survey for the Overseas Development Institute (ODI) found that the contracting of security functions by humanitarian organisations had "become increasingly common worldwide" due to the insecure and violent nature of many of these contexts and increasingly common attacks on aid workers (Stoddard et al., 2008). It should be noted that in some circumstances, such services may be controversial. For example, PMSC involvement in securing sites where natural resources are extracted, such as mines or oil wells, may not be welcomed by local populations; discontent with the powerful business interests involved in such cases can be transferred onto the PMSCs involved, since local people may perceive them to be "complicit" in controversial practices. Individuals and communities may also look to private security providers for protection where they perceive the state to be incapable, incompetent or predatory, though most ordinary people are likely to turn to local security firms rather than international actors.

Secondly, donor states are increasingly turning to the private sector, including PMSCs, to deliver programmes on security and justice in FCAS. This can include measures to fill gaps in existing state provision of security and policing by non-state actors (theoretically on a temporary basis). This has been fuelled particularly by the post-9/11 invasions of Afghanistan and especially Iraq. The scale and extent of the operation in Iraq created a rapid growth in the demand for private military and security services and the companies that delivered them. These services ranged from convoy protection, intelligence analysis, security advice and planning to close protection for diplomatic or aid staff and the protection of embassies, oil production facilities and other essential civilian installations. Such activities were essential to initial US/UK-led coalition military operations and subsequent post-conflict reconstruction activities (Speers Mears, 2009). The extent of PMSC penetration into support for the delivery of national strategic objectives may have even created a "dependency syndrome" whereby the US military in particular became reliant on the services of private contractors to such an extent that they had little control even where those services proved to be inadequate (Singer, 2007). viii

Thirdly, officials and decision makers in FCAS may look to private actors to augment weak state military and security provision. Depending on circumstances, almost any kind of security provision could be required, from close protection of individuals to combat training, interrogation or piloting military aircraft. Again, the operation of these actors may prove controversial, especially where the authority of the state is contested, such as if the state is perceived to have been captured by an individual or group and is not operating in the wider public interest.

Fourthly, in some contexts individuals or groups/political parties may employ private guards, militia or armies to strengthen their hand in contests for influence or control.

Lastly, in some cases international actors have turned to private security provision because states themselves are unsure of the best way to handle a particular security challenge or lack the capacity to address it themselves. A good example is the recent explosion of piracy off the Horn of Africa. Although the European Naval Force Somalia - Operation ATALANTA has a mandate to protect vulnerable shipping off the coast of Somalia "on a case-by-case basis", this has not been enough to reassure the shipping industry. As a result, a major marine insurance broker, Jardine Lloyd Thomson, has proposed an initiative (not yet launched at the time of writing) to establish a private fleet to protect shipping in the Gulf of Aden, which would be funded and run by "shipping associations, charterers, oil companies, insurance underwriters, lawyers, governments and navies" (Costello, 2011). PMSCs have already taken on other anti-piracy functions, such as providing armed guards on vessels and storing their weapons in floating 
armouries in international waters. However, there have been questions about the legal status of these guards, ${ }^{\text {ix }}$ while the weapons-storage issue has been described as a "legal grey area" (Lowe, 2012).

In sum, the market for private military and security service provision continues to grow both in scale and range of activity. Critical to this growth and development has been the readiness and indeed enthusiasm of the main Western donor states to privatise service provision where feasible, including security and development programming in FCAS. When combined with the growing acceptance of the need to consider security and development together, this has not only created opportunities for PMSCs in more traditional security provision, it has also encouraged them to expand into new areas, such as development and humanitarian aid (Stoddard et al., 2008; Lewis, 2012).

By comparison, there has been no inclination among traditional humanitarian or development organisations to move into security markets. The ODI survey's authors noted that despite the discomfort of many humanitarian workers over their close association with private security providers (particularly when it came to armed protection), PMSCs had increasingly "indicated an interest in developing a humanitarian clientele not only as an additional market, but also for the legitimacy and credibility it offers companies seeking to distance themselves from the "guns for hire' image" (Stoddard et al., 2008).

With the large troop withdrawal from Iraq and an anticipated withdrawal of International Security Assistance Force (ISAF) troops from Afghanistan, the opportunities for international PMSCs to play major combat-support roles are diminishing. It has even been suggested that the drawdown of Western forces may "burst" the demand-bubble for security-related services first generated by the Iraq conflict and lead to a rationalisation of the sector (Stoddard et al., 2008). This however fails to take account of the diversity of security services now being demanded and offered, the diversity of customers that want them, and the range of companies that offer them. Moreover, PMSCs have been extremely flexible since their emergence in the 1990s, and there have already been firm indications that the PMSCs that benefitted from the combat-support contracts prevalent in Iraq and Afghanistan are adapting their practices to fit with the new demands and trends in the sector. The 2008 ODI study found that many PMSCs "are attempting to be a 'one-stop shop' offering a full range of risk, security and logistics services. Others are moving into new areas and taking on new roles in risk management, governance and reconstruction" (Stoddard et al., 2008).

This reflects a sense that the market is growing for smaller-scale, stabilisation interventions that straddle the conflict-security-development arena. The added donor government emphasis on ensuring development "value for money" and "results", combined with continued criticism (largely unresolved in the case of Iraq and Afghanistan) of PMSCs' ethical credentials and human rights record, has pushed the private security sector to professionalise and polish its image (Box 3.3). 
In October 2010, the International Peace Operations Association (IPOA) became the International Stability Operations Association (ISOA) to ensure "the support and participation of all key actors in the Stability Operations Industry, including private firms, non-governmental organisations, and governmental and commercial clients." (ISOA, 2012) The association lists one of its tasks as advocating for "the growing and positive contribution of [its member] firms to the enhancement of international peace, development and human security." (ibid.) ISOA members, who must sign up to the ISOA Code of Conduct (ISOA, 2011), include many of the world's biggest contractors in this area (BAE systems, DynCorp International, G4S, International Relief and Development and PAE Inc). Members deliver services that include aviation logistics and maintenance, base support, construction, demining, fleet management, development, intelligence analysis, legal services, recruitment, risk management, security, security sector reform and shelter building in emergencies.

Sources: ISOA (International Stability Operations Association) (2011), ISOA Code of Conduct, Version 13.1, 20 October 2011, ISOA website, www.stability-operations.org/index.php; ISOA (2012) "International Stability Operations Association: IPOA's new name", ISOA press release, www.prnewswire.com/newsreleases/international-stability-operations-association-ipoas-new-name-105686208.html (accessed 22 February 2012)

These concerns over legitimacy, image and professionalism have become increasingly important in PMSCs' thinking and way of working. PMSCs are also now coming into competition with general management contractors or consultants who are also providing large-scale security or development services - or integrated security and development - such as Atos, PricewaterhouseCoopers, Adam Smith International, and Coffey. These companies do not carry the "baggage" that sometimes comes with organisations that started life as hard military and security service providers, and thus may start with a reputational advantage. For example, Adam Smith International describes itself as an international advisory firm that helps reform and improve economies and institutions. It is becoming more involved in working in areas such as conflict resolution and post-conflict reconstruction, such as in South Sudan, where it has been involved in developing parliamentary oversight of the Sudan People' Liberation Army and in supporting the development of a security strategy for national elections. It was recently awarded a governance and security framework agreement by the UK Department of International Development (DFID) for work on security and justice reform, peace and statebuilding. ${ }^{x}$

These questions of reputation and image are very relevant to donor governments making more use of PMSCs in programme delivery, especially in FCAS. Given the importance of good governance in resolving problems in FCAS and in effective state and peacebuilding, it is more than ever in donors' interests to ensure that they are engaging with PMSCs who will "play by the rules".

It should not be forgotten, however, that there are major issues regarding transparency and accountability of PMSCs and their agents that have not yet been satisfactorily resolved. Soldiers in a country's armed forces are accountable for their actions through long-established traditions of military justice and status of forces agreements. ${ }^{x i}$ In contrast, the status of and rules applying to private military and security contractors operating in foreign lands is frequently ambiguous, particularly in FCAS.

Governments do make efforts to wield control. However, in Western countries the tendency has been to promote self-regulation of PMSCs through voluntary codes of conduct. There tends to be a stronger inclination to institute legislative control in the countries where PMSCs routinely operate, but in cases of contested authority or when capacity is very low, this is clearly a difficult business. Section 5 looks in more detail at the existing policy framework that is in place to control the international markets in security and military assistance. 


\title{
NOTES
}

\begin{abstract}
' Victor Bout, recently sentenced in the US to 25 years in prison for conspiring to sell anti-aircraft missiles and other weapons to men he believed were Colombian terrorists, stands as the most notorious example. Formerly an officer of the KGB, following the collapse of the Soviet Union Bout leveraged his language skills and military contacts and bought three or four Antonov AN-12 cargo planes for a reputed USD 120000 (Daly, 2008). He and his companies became a regular feature in UN embargo panel reports. After years of being under an INTERPOL arrest warrant, he was eventually arrested after an elaborate sting operation by the US Drug Enforcement Administration.
\end{abstract}

ii See for example Ingram and Davis (2001).

iii Offsets involve suppliers investing in production capacity in the recipient state. For direct offsets, this investment will relate to the arms transfer contract itself; indirect offsets involve investment in unrelated activity. Offsets are an increasingly common element of major arms purchases. The World Trade Organization rules forbid offsets in other sectors.

iv See for example, Quinn (2012).

${ }^{\vee}$ The General Agreement on Tariffs and Trade (GATT) allows any contracting party to take "any action ... it considers necessary for the protection of its essential security interests relating to the traffic in arms, ammunition and implements of war ..." (Article XXI (b) (ii) of the GATT, 1947, www.wto.org/english/docs e/legal e/gatt47 02 e.htm\#top).

vi In 2000, the US Department of Commerce claimed that the defence sector accounted for $50 \%$ of all global bribery allegations between 1994 and 1999, despite accounting for less than 1\% of total world trade (US Department of Commerce Trade Promotion Co-ordinating Committee Report, March 2000).

vii Though even here, as the range of services offered by PMSCs increases, exceptions to this rule are being created. For example, in the US a private firm maintains a fleet of 30 combat-capable military aircraft (including two MiG-29 jets bought from Kyrgyzstan) and have a contract to fly them-using their own private pilots-in training exercises against US Navy pilots (Hoffman, 2005).

viii The title of Singer's paper was a colloquial reference to this dynamic: "Can't win with 'em, can't go to war without 'em".

${ }^{i x}$ The UN monitoring group on Eritrea and Somalia points out that "armed private maritime security companies have no official status under the UN Convention on the Law of the Sea, which raises serious questions with respect to liability for actions they may take and the damage, injuries or deaths they may cause" (United Nations, 2011b).

${ }^{x}$ See www. adamsmithinternational.com/.

${ }^{x i}$ Status of forces agreements (SOFA) establish the legal basis for a foreign nation's military forces while they are on the territory of a host country with which the SOFA is signed. This includes clarifying to which laws military forces and their personnel are accountable and their liability for prosecution. 


\section{Impacts on conflict and fragility}

Here we look at the impact of international markets in mil/sec assistance on fragile state capacity and legitimacy. Broadly speaking, impacts on capacity can be grouped into two different but related categories:

1) Activities that build state capacity to provide security. These can increase legitimacy and service provision, while reducing the likelihood of conflict and fragility.

2) Activities that erode state capacity and legitimacy. These result in an increased risk of fragility and conflict.

However, the distinction is often fine as similar activities, such as procuring the support of private security providers, can have both positive and negative implications. The following sections give a brief overview of these potential positive and negative impacts.

\subsection{Positive impacts: building essential state capacity}

International markets in military and security assistance offer access to the arms, expertise and capacity that can enable states to provide security for their citizens. Properly regulated mil/sec assistance can provide positive incentives for legitimate and responsible governance; promote democratic norms for oversight, transparency and accountability of the security sector; and facilitate strategic partnerships and alliances between states that share a positive agenda for peace. Such assistance can also render peacekeeping and peace support operations more effective. Here we review the enabling conditions that allow for these positive impacts.

\section{Responsible arms transfers}

The legitimate international market in conventional arms, ammunition and related security equipment allows states to procure the equipment they need for their legitimate defence and security needs. The limitations placed through national and regional arms control regimes on states' ability to access such markets are principally related to the legitimacy of the intended end use of the weapons; the national and regional context with regards to human rights, conflict and development; and the capacity of the state to fulfil its end-user requirements. In theory, therefore, a robustly regulated international market in arms and related equipment can both thwart those wishing to procure weapons to wage war or commit human rights violations while driving up standards and transparency among those wishing to access weapons for legitimate self-defence and internal security purposes.

\section{Private security providers}

Private security providers can be an important resource for states with weak and under-resourced security services and can play a vital role in enhancing state legitimacy if their use is appropriate, regulated and transparent. Almost all states use some kind of private security provider to complement or supplement state security forces at various levels, with varying degrees of success. A striking example is the Executive Outcomes operation in Sierra Leone between 1995 and 1997, where a South African private security company hired by the Government of Sierra Leone used a relatively small number of highlytrained men and sophisticated equipment, including helicopter gunships, to repel Revolutionary United Front (RUF) rebels from several diamond mining areas and return them to state control. This demonstrates how international mil/sec assistance can directly and dramatically address conflict issues. However, the same example also exposes some of the challenges to using private actors for combat purposes, as the diamond-mining concessions granted to Executive Outcome partners Branch Energy as part of the deal led to a non-transparent "mortgaging of the nation's assets" (Sierra Leone Truth \& Reconciliation Commission, 2004) and damaged the future ability of the state to provide services for its population (Montague, 2002). 


\section{Enabling peacekeeping operations}

Among the more visible international responses to conflict and fragility are international peacekeeping and peace support operations. Such operations are becoming increasingly complicated, being "called upon not only to maintain peace and security, but also to facilitate the political process, protect civilians, assist in the disarmament, demobilization and reintegration of former combatants; support the organization of elections, protect and promote human rights and assist in restoring the rule of law" (UN, 2012).

However, many developed countries are reluctant to support peacekeeping operations with their own wellequipped national forces and are too financially stretched to provide adequate funding for peacekeeping interventions (Gichanga et al., 2010). The vast majority of peacekeeping personnel therefore come from countries whose armed forces may lack advanced capabilities or equipment. Thus, private contractors frequently fill the gap, playing critical roles in peacekeeping operations. Examples include:

- PAE Inc.'s logistical support to the African Union Mission in Darfur became the "logistical backbone" of the operation (Gichanga, 2010).

- Bancroft International gave extensive support to African Union Mission in Somalia (AMISOM) and the Transitional Federal Government (TFG) militaries in Somalia' (UN Security Council, 2011).

- Blue Sky's supervision of the ceasefire in Aceh (Renouf, 2007).

It is worth noting that these companies provided a range of services from critical infrastructure provision (PAE Inc.) through to the delivery of military supplies, training and in-combat assistance (Bancroft International). Other potential benefits of using private security firms in peacekeeping operations include their ability to "sidestep" complicated political realities that may ensnare states, the speed at which they can be deployed, and their effectiveness compared to sometimes poorly-trained and equipped national forces from some developing countries.

\subsection{Negative impacts: undermining state legitimacy and capacity}

Although international markets in mil/sec assistance can have benefits, they are always at risk of being used in a way that makes the situation even worse. In particular, irresponsible groups can directly perpetrate human rights abuses, property damage and loss of life. Grave, persistent and widespread illegitimate use of force by state security services, violence perpetrated by non-state armed groups (NSAGs), the inappropriate use of private security providers by states, illegal behaviour by private security providers themselves, massive corruption in arms deals and the diversion of state resources from other essential services can all threaten state legitimacy and increase the risk of fragility and violent conflict. Further impacts can include the exacerbation and prolonging of conflict and instability, undermining work on conflict prevention and complicating both emergency humanitarian relief and longer-term development efforts.

\section{Contributing to human rights abuses and violations}

There is a vast literature documenting breaches of international humanitarian law, international human rights law and other illegitimate uses of arms and security equipment accessed via international markets by state and non-state actors alike. ii The international community has acknowledged on numerous occasions that irresponsible and illegal arms transfers contribute to serious violations of human rights and international humanitarian law. This has been one of the key motivating factors for efforts underway in the UN to agree a global legally-binding Arms Trade Treaty (see Section 5 below).

PMSCs have similarly been criticised for alleged human rights abuses, most visibly in Iraq, with cases such as the killing of 17 civilians by Blackwater operatives at Nissour Square in 2007.ii 


\section{Prolonging and exacerbating conflict}

Despite international efforts to stem the flow of arms and related equipment and services into conflict zones, including UN Security Council arms embargoes, there is a significant body of evidence showing that arms supplies continue to reach warring parties, fuelling existing conflict and rendering peace more difficult. For example, the UN Monitoring Group in Somalia has identified numerous sources of arms and ammunition supplied to various armed groups in breach of an arms embargo, with Eritrea featuring regularly. The Monitoring Group has also brought to attention the crucial importance of Yemeni commercial networks in supplying arms to different factions in Somalia. One report stated that "commercial imports, mainly from Yemen, remain the most consistent source of arms, ammunition and military material to Somalia" (UN Security Council, 2008).

\section{Corruption and the diversion of state resources away from essential services}

The circumstances in which arms are procured may well pose a risk to conflict and security. According to estimates by Transparency International, in 2005 the global cost of corruption in the defence sector was at least around USD 20 billion per year, equalling all the official development assistance provided to Iraq, Afghanistan, Congo (DRC), Pakistan and Bangladesh combined (Transparency International, 2011). Often shielded from scrutiny by their association with national security, typical corrupt transactions can include payments to decision makers during procurement processes and "commission" payments to advisors related to arms deals. The impact of this corruption is most keenly felt in FCAS, diverting much-needed state resources away from socio-economic development, and undermining transparent governance and the rule of law.

Where government transparency is weak, efforts to regulate and control PMSCs also risk becoming hostage to corruption - for instance, legitimising illegal activities or providing means to reward allies or punish enemies through the licensing process. In Afghanistan, for example, many domestic private security companies (PSCs) have been implicated in armed crime, such as bank robbery, and some observers point out that legitimising "militias" by giving them quasi-legal status as PSCs may undermine public trust in the authority that grants them this status if they continue to act criminally (Spearin, 2008). There have also been widespread reports of corruption within ministry of interior departments that regulate PSCs, with some political figures allegedly acting as "patrons" for certain PSCs with whom they maintain close ties and sometimes use as their own personal militias. The UN Human Rights Council notes that licences have been granted to PSCs in Afghanistan owned by high-ranking government officials (despite a law which explicitly prohibits this) and suggests that "the process of selection and registration of a limited number of 39 PMSCs seemed to be responding more to commercial and personal interest than a competitive process taking into account human rights considerations" (UN Human Rights Council, 2010b). Indeed, there have been reports of Ministry of Interior officials in Afghanistan using their power to enforce registration to settle political scores or extract bribes, rather than to target poorly performing or abusive companies (Spearin, 2008).

\section{Bypassing the state}

Another risk is that well-intentioned programmes to reform the state are undermined or bypassed entirely because a private alternative exists. For example, the widespread recruitment of Afghans into private security firms (whether wholly local or internationally-owned) may help "keep militia members busy" (Renouf, 2007). But some point out that "recruiting these militia members en masse, with their estimated 44,000 weapons... has largely bypassed DDR [disarmament, demobilisation and reintegration] efforts" (Spearin, 2011). NATO officials have reported concern that PSCs are not integrated into any kind of coordinated security management framework and that the high salaries they offer provide a strong incentive for people to join the Afghan National Army and Afghan National Police training programmes to improve 
their skills before deserting and joining a PSC for a higher-paid, and potentially less dangerous, job (Spearin, 2011).

\section{Subtle "securitisation" of development}

Even when well-regulated and ethically-sound, the use of either private security companies to design and deliver relief and development work or private sector management consultancies to deliver securityrelated development work, such as security sector reform interventions, risks a subtle kind of securitisation. Many development and humanitarian actors have become concerned in the previous decade that development work risks being "securitised" by being co-opted or distorted by the security and military priorities and interventions of key international actors in fragile contexts. Security-related development work - which addresses security and justice as key factors of and obstacles to development - is therefore a particularly sensitive area (Saferworld, 2011). The concern here is that private companies may be less likely to adhere to key principles and good practice for development. They most often have the expertise to deliver large-scale interventions for central government - infrastructure or extensive "train and equip" reform programmes, for instance - but they may be less likely to include citizens' voices or allow for the active participation of communities in their service provision. Yet inclusivity, accountability and citizen participation are becoming central in recent thinking on conflict and fragility as key elements that contribute to long-term peace and stability. iv 


\section{NOTES}

\footnotetext{
' Including, for instance, working with the TFG to improve the accuracy of their artillery targeting - an issue which many humanitarian and human rights organisations had highlighted was causing high-levels of civilian casualties in Somalia.

ii In addition to the reports of UN panels see for example the numerous reports by Human Rights Watch and Amnesty International: www.hrw.org; www.amnesty.org;

iii Human Rights First (2008) suggests that this case crystallised concerns about a culture of impunity among private security contractors.

iv See for example World Development Report 2011: Conflict, Security and Development (World Bank (2011), the UK's Building Stability Overseas Strategy (UK Government (2011a), and the New Deal for Engagement in Fragile States (International Dialogue on Peacebuilding and Statebuilding, 2011).
} 


\section{Analysis of policy response to date}

The discussion above suggests that given the scale and potential impact of the more negative aspects of international markets in $\mathrm{mil} / \mathrm{sec}$ assistance, robust regulation is required at both the national and international levels. Indeed, there have been extensive formal efforts to better control the international trade in arms and, to a lesser degree, the activities of companies providing services within markets for international security and military assistance. This section will not cover every initiative; instead we paint a general picture and analyse some of the relative strengths and weaknesses of key control mechanisms. It is worth noting that to date the policy response has focused primarily on the better regulation of the supply of mil/sec assistance (both equipment and services) via international markets. Policy responses give much less attention to tackling the reasons why, when and what sort of assistance is demanded by states and whether it is appropriate.

\subsection{Controlling international transfers of military and security equipment}

The end of the Cold War and the revelations about supplies of arms into the Iran-Iraq war of the 1980s ushered in a new era in the control of international transfers of conventional military and security equipment. Over the last two decades there has been a growing trend towards regulation and transparency. There is now also significant ad hoc bilateral interaction and a growing number of formal regional and international mechanisms for co-operation and the harmonisation of practice between states, addressing issues such as legislative development, control lists, authorisation processes, transport management, post-delivery checks and controls, and enforcement practices. The section below outlines the major elements of these policy responses and highlights some of their shortcomings.

\section{Regional and international regulations: piecemeal and poorly enforced}

The trade in conventional military and security equipment is acknowledged by all states to be a legitimate activity, and under international law (UN Charter Article 51) states are entitled to acquire conventional arms for their legitimate self-defence and internal law-enforcement needs. 'However, it is generally agreed by states that no international transfer of items classified as "strategic" or "controlled" (terms which are generally used by states to describe military and security-related equipment and services) should take place without the express permission of the exporting and importing state. Nor can a state be forced to authorise a transfer against its wishes.

However, in a limited number of extreme cases - though more frequently since the end of the Cold War the UN Security Council has in effect judged that the normal entitlement to acquire arms no longer applies and has imposed embargoes on the transfer of conventional arms to named destinations or recipients. All states are obliged to honour these embargoes. At the time of writing there were $13 \mathrm{UN}$ arms embargoes in force, ${ }^{\text {ii }}$ while the question of applying an arms embargo on Syria was the subject of intense debate. Embargoes have also been agreed by regional organisations (such as the Organisation for Security and Co-operation in Europe (OSCE), the European Union (EU), the African Union (AU) and the Economic Community of West African States (ECOWAS), and sometimes applied unilaterally. Unlike UN Security Council embargoes, however, these cannot bind the actions of any actor not party to that decision.

Beyond embargoes, the standard practice is for states to make transfer decisions on a case-by-case basis as a matter of national discretion. Although the precise language differs depending on the agreement or the national system, many states are now formally committed to considering the impact the transfer might have on human rights, humanitarian law, internal repression, destabilising accumulations of arms, an existing conflict, regional and international peace and security, socio-economic development, crime, corruption, terrorist acts and diversion, among others. Many of these are clearly of particular salience with regard to conflict-affected or fragile environments. It should be noted, however, that many states have not 
so far translated their policy commitment to control exports on the basis of such criteria into strong assessment and decision-making mechanisms that would ensure they are implemented effectively.

At the international level, relevant agreements include:

- P5 Guidelines for conventional arms transfers, agreed by the five permanent members of the UN Security Council (UN Security Council, 1991);

- UN General Assembly Guidelines for International Arms Transfers (UN General Assembly, 1996)

- The UN small arms and light weapons process, commencing with the agreement of the 2001 Programme of Action to Prevent, Combat and Eradicate the Illicit Trade in Small Arms and Light Weapons in All Its Aspects (PoA) (UN, 2001)

- The Protocol against the Illicit Manufacturing of and Trafficking in Firearms, Their Parts and Components and Ammunition, supplementing the UN Convention against Transnational Organized Crime (Firearms Protocol) (UN General Assembly, 2001; came into force in 2005)

Relevant regional and multilateral agreements include:

- OSCE Principles Governing Conventional Arms Transfers (OSCE, 1993)

- The Wassenaar Arrangement (Wassenaar Arrangement, 1995)

- Organization of American States Inter-American Convention Against the Illicit Manufacturing of and Trafficking in Firearms, Ammunition, Explosives, and Other Related Materials (OAS, 1997)

- EU Code of Conduct on arms exports (EU, 1998), which was in 2008 replaced by the legallybinding EU Council Common Position defining common rules governing control of exports of military technology and equipment (EU, 2008)

- OSCE Document on SALW (OSCE, 2000)

- Southern African Development Community Protocol on Control of Firearms, Ammunition and Other Related Materials (SADC, 2001)

- Best Practice Guidelines for the Nairobi Protocol for the Prevention, Control and Reduction of SALW in the Great Lakes Region and the Horn of Africa (Nairobi Protocol, 2004)

- ECOWAS Convention on SALW, their Ammunition and other Related Materials (ECOWAS, 2006)

- Central African Convention for the Control of SALW, Their Ammunition and All Parts and Components That Can Be Used for Their Manufacture, Repair and Assembly (UN, 2010).

This diversity of agreements and instruments demonstrates the piecemeal way in which the international community as a whole has addressed this issue. Most of these responses are political in nature, restricted in scope in one way or another, and/or structured in such a way as to give considerable interpretive freedom to states. Some remain largely policy on "paper" and have yet to make it onto national statutes or be implemented in full. The result is an inconsistent and often confusing patchwork of legal and political jurisdictions which, as it currently stands, fails to adequately regulate the supply of weapons into conflict-affected and fragile states. There is a large body of evidence showing that even the most rigorous transfer control regimes (including UN Security Council arms embargoes) are systematically violated with impunity.iii

The preventive nature of arms transfer control means that failures of control mechanisms - when irresponsible or illicit transfers of arms and related equipment are exposed - are more likely to be publicised than successes in regulating transfers effectively. However, the fact that weapons are still readily available to those who plan to use them illegally and irresponsibly in many FCAS shows that the current policy response is inadequate to mitigate the risks to conflict and fragility posed by arms transfers. 
The current Arms Trade Treaty (ATT) process has the potential to address some of these shortfalls. ${ }^{\text {iv }}$ It was conceived as a global legally-binding instrument to regulate international arms transfers in a comprehensive manner. It was set in train by UN General Assembly resolution 61/89 (2006) and started to be formally negotiated in July 2012. However, regardless of how strong the ATT might be, this type of overarching instrument will require more detailed elaboration of its provisions in other fora and formats, including the development of legislation and operational guidance at national level. Implementation will ultimately rely on national level political will.

\section{Controlling intermediaries}

Controlling the intermediaries (including brokers, transporters, financiers, freight forwarders etc.) who facilitate arms transfers into FCAS is a complex business and until recently few states included brokering controls in their national systems. This is changing; there are now more than 40 states that have some kind of legal framework for controlling brokers, while reference to arms brokering is now increasingly common in regional agreements. Meanwhile, work is underway at the UN to control the brokering of conventional arms. In 2007 a Group of Governmental Experts on SALW brokering "encouraged [states] to develop adequate national laws, regulations and administrative procedures to control SALW brokering activities" (UN General Assembly, 2007, para 63 i), while UN Security Council Resolution 1540 obliges states to regulate brokering to prevent the proliferation of nuclear, chemical, or biological weapons and their means of delivery (UN Security Council, 2004).

Some attention has recently been paid, predominantly in Europe, to the role of air transportation in delivering arms to conflict zones and fragile environments. This led the Wassenaar Arrangement to adopt in 2007 Best Practices to Prevent Destabilising Transfers of SALW through Air Transport (Wassenaar Arrangement, 2007). These best practices, also adopted by the OSCE in 2008, recommend that where SALW are to be transferred by air, exporters should be required to give additional information about carriers and routes, on the grounds that this type of information may point to diversion risks and possibly problematic transfers.

However, the effectiveness of measures to regulate the activities of arms brokers and transporters is poor. The ability of arms brokers to play their organisational role from almost anywhere on the planet creates significant enforcement difficulties and the complex networks in which intermediaries operate further hamper efforts to regulate them. Where such laws do exist, few cases are actually brought before the courts and fewer still result in successful prosecution. The result is that states and NSAGs alike can exploit these covert networks to secure the arms and ammunition they require when legitimate sources are shut off to them through regulation.

\section{Other technical issues}

Steps have also been taken to deal with other technical issues relevant to international arms transfers. In 2005, under the auspices of the UN Programme of Action on SALW, states agreed the politically-binding International Instrument to Enable States to Identify and Trace, in a Timely and Reliable Manner, Illicit Small Arms and Light Weapons (UN, 2005). In 2011, a technical review panel consisting of experts from member states, with the support of international, governmental and non-governmental organisations working under the UN SaferGuard Programme, completed a series of International Ammunition Technical Guidelines. These guide states on best practices in a wide range of issues such as ammunition accounting, transportation and demilitarisation and destruction (UNODA, 2011). The UN Co-ordinating Action on Small Arms is currently developing International Small Arms Control Standards, which will consider issues such as stockpile security, community safety and transfer controls. ${ }^{\vee}$ At the regional level, though with a broader relevance, the South Eastern and Eastern Europe Clearinghouse for the Control of SALW has developed a series of Regional Micro-Disarmament Standards and Guidelines to support SALW control efforts at the operational level (SEESAC, n.d.). These cover topics such as legislation, marking and tracing, storage and export documentation. 
While clearly useful in providing some degree of consistency and technical guidance on various elements of military and security equipment control, these approaches are constrained by the capacity and political will of states to use or enforce them. As with other individual elements of transfer control they will have little impact on unregulated transfers; they also need to be implemented within a broader, more comprehensive framework. This is another argument in favour of a comprehensive Arms Trade Treaty, as it could provide this framework (see Section 6).

\section{End-use documentation and checks}

Checks on end-use or end-users are now common practice. Most states will expect some kind of documentation with details of proposed end-use and/or the end-user when considering a possible export. Following a number of cases where end-use documentation proved to be forged or otherwise worthless, which resulted in arms shipments finding their way into conflict zones, it is now good practice for follow-up checks to be made where there are any concerns about end-use assurances. Transfer authorisations increasingly include restrictions on re-export, to the point where exporters may reserve the right to check on the whereabouts and use of equipment post-delivery. Most practices have been developed at the national level, although there has been some regional co-operation among states to identify best practice and standardise end-user certification and procedures for some conventional arms. ${ }^{\text {vi }}$ There have also been calls to establish a global standard, but there are currently no concrete plans to pursue this.

\section{Transparency and information sharing vii}

Another key element of a comprehensive arms transfer control strategy is the opportunity and ability to hold states accountable for their actions. Information about national transfer control systems, transfer

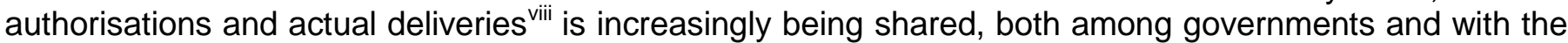
public. This may occur through national reporting by governments, participation in regional or global reporting regimes, or collection and organisation of data already in the public domain (e.g. through defence industry self-publicity) by non-governmental actors.

Over the last 20 years, the level of information sharing and transparency on conventional arms transfers, in particular transfer authorisations or actual deliveries, has advanced significantly. This began with the agreement of the UN Register of Conventional Arms in 1991, which committed states to report publicly on any imports or exports of seven categories of major conventional arms (UNODA, n.d. a). Over time, this has been developed further with states also now encouraged to submit information on transfers of SALW and on national holdings and domestic purposes. However, reporting is not universal, and in recent years the number of reports has fallen. Nevertheless, more than 170 states have reported at least once during the lifetime of the register.

Under UN Security Council Resolution 1540 on preventing the proliferation of nuclear, chemical, or biological weapons, states are obliged to report on the steps they are taking to implement the resolution. ${ }^{\text {ix }}$ In addition, under the UN Report on Military Expenditures states are also invited to report to the UN on their military spending in the previous year (UNODA, n.d. b). States are also invited to report on their implementation of the UN Programme of Action on SALW (POA), which provides the framework for activities to counter the illicit trade in small arms. ${ }^{x}$ All of these reports are in the public domain. It should be noted that in many arms transfer control instruments states are "invited" rather than obliged to report on implementation. As with some other aspects of the policy response outlined above, transparency and information sharing remains largely a voluntary exercise dependent on the political will of those states involved. As such it is largely limited to the willing; serious thought needs to be given on how to engage states that are emerging as increasingly significant suppliers but who have yet to develop a culture of transparency. 


\section{Border management}

International bodies such as INTERPOL and the World Customs Organisation (WCO) also play a role in the management of international arms transfers. INTERPOL supports efforts to trace firearms that have been traded internationally. It does so through a Firearms Program composed of three major components:

1) a Firearms Reference Table, which enables investigators to identify a firearm before submitting a trace request;

2) the INTERPOL Firearms Trace Request; and

3) the INTERPOL Ballistics Information Network, so as to facilitate the transnational sharing and comparison of ballistic data.

WCO is helping to implement the Firearms Protocol. In addition, it has been developing model risk indicators for detecting illicit weapons shipments, and publishing regional analytical reports on seizures of firearms and new trends of concealment and smuggling, all of which are made available to frontline officers.

While border management is clearly an important element in regulating the actual flow of arms and related equipment into conflict-affected and fragile states, in reality the capacity of many FCAS to police their extensive land and sea borders is extremely limited and they remain largely porous. This is an area with potential cross-over into other areas where border management is also important, such as transnational organised crime, migration and NSAGs.

\subsection{Controlling international markets in security and military services}

The policies for regulating international markets in security and military assistance are less advanced than those for regulating military and security equipment, particularly normative measures. The following section gives a brief overview of international and multilateral efforts and offers some national case studies to prompt further discussion on implementation.

\section{International and multilateral control efforts: the Montreux Document and the International Code of Conduct for Private Security Providers}

In 2006, the Swiss Government and the International Committee of the Red Cross launched the Swiss Initiative, which resulted in the Montreux Document on Pertinent International Legal Obligations and Good Practices for States related to Operations of Private Military and Security Companies during Armed Conflict (Montreux Document, 2008). Whilst not in itself a legally-binding document, it compiles the relevant existing international legal obligations of states variously involved in contracting and hosting PSCs. It also provides a set of good practices that these states could implement to encourage PSC compliance with international humanitarian law and international human rights law.

Building on the Montreux Document, the Swiss government, in co-operation with the UK and USA particularly, began work in 2008 on an International Code of Conduct for Private Security Providers (ICOC). While the Montreux Document focused on the legal obligations of states, the ambition of the ICOC is to clarify international standards for PSCs operating in "complex environments". The ICOC also seeks to establish an independent mechanism for improving the oversight and accountability of PSCs. At the time of writing, the ICOC has attracted over 350 signatories (ICOC, 2012) and been enthusiastically incorporated into the principles, rhetoric and advocacy of industry associations such as the ISOA (see Box 3.3) and British Association of Private Military and Security Companies, as well as many of their members. The ICOC steering committee is currently considering a draft annex covering maritime security services (see below). It is envisaged that certification and monitoring of compliance will be overseen by an independent oversight mechanism, most likely housed in Geneva which would have the authority to 
impose sanctions on non-compliant members - although in the proposals these are limited to suspension or termination of membership of the ICOC.

However, the power of the ICOC's sanctions depends entirely on the reputational risk PSCs see in nonmembership of (or, more precisely, visible suspension from) the ICOC. Subsequently, its ultimate efficacy is likely to be determined by how rigorously those contracting PSCs require them to hold current ICOC certification. Both the UK and US have indicated that they will require ICOC certification as part of procuring PSC services, but given the penetration of private security firms into these (and many other) states' ability to wage war, engage in high-priority post-conflict reconstruction or stabilisation, or, increasingly, deliver rising aid budgets in FCAS with reduced overhead costs, it remains to be seen what course of action might be taken if a contracted company's membership of the ICOC was suspended or terminated midway through a strategically-important programme or other contract.

Whilst the ICOC and its associated independent oversight mechanism certainly offer valuable potential for helping to drive up international standards for PSCs, the risk may be that their ability to positively influence behaviour is, at best, patchy and, at worst, overshadowed by their use as a legitimising brand by companies not necessarily fully complying with the code. The ICOC, therefore, would play the strongest role if used alongside complementary measures to support the development of national legislation and promote effective public scrutiny of the security sector in host countries.

\section{The Sarajevo Process}

In 2006, convened under the leadership of the INGO Saferworld and the South Eastern and Eastern Europe Clearinghouse for the Control of Small Arms and Light Weapons (SEESAC), the Sarajevo Process brought together a range of stakeholders from PSCs in Bosnia, their clients, officials from the Bosnian government and international experts to look at strengthening standards in the provision of private security services in Bosnia.

The main outputs of the Sarajevo Process were a code of conduct for PSCs (SEESAC, 2006a) and a set of guidelines for those procuring PSC services (SEESAC, 2006b). These two documents were seen as mutually reinforcing. Together they provide a set of voluntary standards for the Bosnian private security industry and its clients.

However, Saferworld's evaluation of the Sarajevo Process noted that, although there had been some positive outcomes of the process, implementation, as well as uptake, had been extremely poor (Saferworld, 2007). They conclude that the primary reason PSCs in Bosnia had not made significant progress in putting the Sarajevo Code of Conduct into practice was that it was not legally binding. They note that "... a self-regulatory voluntary instrument is insufficient to adequately regulate the industry and to improve the standards of the sector as a whole".

Indeed, the main thrust of Saferworld's evaluation of the Sarajevo Process is that whilst voluntary regulation may be a valuable stepping stone towards more formalised regulation, it is no substitute for well-implemented national legislation. Consequently, in the absence of adequate legislation or in circumstances where it is poorly enforced, the voluntary approach should be seen as supporting the development and enforcement of formal legislation by engaging all relevant actors in a drive towards improving standards.

\section{Regulating armed guards on commercial shipping}

As noted in Section 3, the increase in piracy, particularly off the Horn of Africa, has led to the use of armed guards on commercial ships. Until recently, this was largely discouraged, less because of ethical issues than because of concerns over costs, the risk of damage to vessels and cargo and potential legal complications for the commercial shipping sector, which is highly regulated and scrutinised. ${ }^{\mathrm{x}}$ 
The International Maritime Organisation has issued "interim" guidance on the use of privately contracted armed security personnel on board ships, which suggests that "flag State jurisdiction and any laws and regulations imposed by the flag State concerning the use of private security companies apply to their vessels. Port and coastal States' laws may also apply to such vessels" (IMO, 2011). In addition, the IMO guidance suggests some relatively robust assessment measures be undertaken before using "relatively immature" PSCs. It stresses that they are "not an alternative" to the existing Best Management Practices for Protection against Somalia Based Piracy - the industry-wide protocol for operating in these waters (BMP4, 2011).

In response to these concerns from its potential customer base, the maritime security industry has rapidly stepped up efforts to develop a trade body to "promote high standards" in the sector (as well as acting as an industry advocacy body, similar to the ISOA). The Security Association for the Maritime Industry (SAMI) was set up in 2011 and is "seeking to attract members to join and set minimum standards of conduct and procedures" (Ince and Co., 2011). Although primarily aimed at land-based security companies, a maritime annex is being drafted to the ICOC and SAMI is encouraging all of its members to join.

Perhaps the most powerful lesson from this experience is the impact that concerned and motivated clients can have on the regulation of international markets for security assistance, especially where they represent significant commercial interest. However, the complex balance between supply and demand is likely to mean that, without effective external regulation, the promotion of higher standards from within industry itself may be insufficient. As a partner in one international law firm tracking the development of the maritime security sector put it, "it is likely that those companies prepared to separate themselves from the pack will find themselves preferred, but the danger is... that an increase in demand for armed guards will lead to a decrease in quality" (Ince and Co., 2011).

\section{Guidelines for contracting PSCs}

The policy approach to date for regulating the international market in military and security assistance has primarily concentrated on technical aspects such as registration, licensing and recruitment. There has been little focus on when and why it may be appropriate for states or other entities to employ private security services and what the implications may be for state legitimacy, service delivery and ultimately the risk of conflict and fragility.

One exception to this is the recent publication of Engaging with Private Security Providers by the European Interagency Security Forum (EISF), a platform for Security Focal Points from European humanitarian agencies, This aims to "provide guidance in the decision-making process of humanitarian NGOs on when and how to involve PSPs [private security providers] in security arrangements" (EISF, 2011).

The guidelines provide a set of suggested "core competencies" that contracting agencies should look for in potential service providers. They suggest over 80 individual checks or questions that should be considered when making a decision on the use of private security providers.

This guidance is relatively new and thus it is not yet possible to assess how widely it is being used, whether it has improved the quality and effectiveness of security provision contracted by humanitarian service providers, or whether their potential negative impacts in FCAS have been minimised as a result. This would be a valuable piece of research and could also suggest how to further strengthen the guidance (for instance, the guidance currently contains little on how to assess the potential impacts of PSP service provision on the operating context -integrating some of the well-established tools for assessing risk to conflict dynamics that exist within conflict sensitivity literature would thus be beneficial). 
Rather than responding to the weakness of state provision by contracting out tasks to an under-regulated private security sector, some countries have sought to respond by retaining a state monopoly of the use of force and then charging for services that they cannot afford to deliver for free. In Somaliland, for example, the government has established a Special Police Unit (SPU) with international support which has a legal monopoly on providing protective services for visiting dignitaries and aid workers. This has established a source of revenue for the Somaliland authorities and provided them with a way of excluding many private security firms from operating within Somaliland. Although questions have been asked about the professionalism of the SPU and its relevance for security and justice services to communities living in Somaliland, it is notable that the UN Monitoring Group on Eritrea and Somalia found little evidence of deleterious impacts of PSCs in Somaliland as compared with multiple and serious examples in the rest of Somalia. 


\section{NOTES}

\footnotetext{
'Note that this charter sets conventional arms apart from chemical, biological, radiological and nuclear (CBRN) weapons, trade in which is prohibited under various UN instruments. It should be noted, however, that debates about legitimacy are still live for some types of arms, e.g. cluster munitions.

ii See the Stockholm International Peace Research Institute arms embargo database, www.sipri.org/databases/embargoes.
}

iii See for example www.hrw.org; www.amnesty.org; and various UN Panel of Expert reports for Angola, the Democratic Republic of Congo, Liberia and Sierra Leone, etc.

iv See www.un.org/disarmament/ATT.

${ }^{v}$ CASA Project on International Small Arms Control Standards (ISACS), www.un-casaisacs.org/isacs/Welcome.html.

${ }^{\mathrm{vi}}$ See, for example OSCE (2004); and EU (2009b).

vii In this paper, information-sharing refers to circulation of data to other governments (bilaterally or more generally) that is not placed in the public domain, whereas transparency refers to placing data in the public domain.

viii Throughout this paper, authorisation refers to a decision by a government to allow a transfer, while delivery refers to a change in ownership/control of the arms in question to an actor under the jurisdiction of another sovereign power, even if the items to not physically cross any national border. Under this definition, a change of ownership/control of arms from country A to country B while both are engaged in a UN-authorised peace-support operation in country C would be classified as a "delivery". Note that these two terms are not the same. Transfers may be authorised but never actually be delivered, and unauthorised deliveries can and do occur.

ix 1540 Committee, National Implementation, www.un.org/en/sc/1540/national-implementation/guidelines-forreporting.shtml, accessed 8 September 2012.

${ }^{x}$ See www.poa-iss.org/poa/poa.aspx.

${ }^{x i}$ This is largely uncharted water, but the relationship between the use of armed guards at sea and SALW controls provides some obvious ideas of where difficulties may lie. For instance, Ince and Co. suggest that "sometimes, oblivious to the source and provenance of the weapons [carried by PSCs], Flag States approval is given and their lead is then followed by underwriters. The result is that they may simply be approving unlicensed weapons onboard" (Ince \& Co, 2011). At the same time, the UN Monitoring Group for Eritrea and Somalia claims that "some governments both inside and outside the region have begun to take advantage of this booming business, offering expensive, customised permits that allow private maritime security companies to operate from their ports with weapons, personnel and equipment and, in some cases, private patrol vessels. Some governments generate additional income by leasing out state-owned weapons to licensed private maritime security companies." (UN Security Council, 2011, authors' italics) 


\section{Entry points for follow-up initiatives}

This section attempts to identify entry points for addressing some of the dynamics that have been raised in preceding sections.

\subsection{Entry point 1: Expanding and consolidating international and regional regulatory frameworks}

Despite the proliferation of agreements and technical approaches to arms transfer control, and some attempts at regulating military and security services, their piecemeal nature, many loopholes and lack of political will to implement them consistently pose a significant risk to conflict and fragility. To address these shortcomings, we put forward the following actions for INCAF members:

- Adopt and ratify an international treaty on the arms trade which has comprehensive scope, rigorous criteria, requires thorough public reporting and meaningful implementation mechanisms. This should occur regardless of the outcome of the July 2012 UN diplomatic conference to agree an international arms trade treaty.

- Develop a more robust International Code of Conduct for Private Security Service Providers (ICOC). Ensure political momentum and resources for robust monitoring, verification and enforcement mechanisms, as well as crucial support for the development of complementary national legislation in post-conflict countries with limited resources and capacity. Consider building on the networks, legitimacy and buy-in that the ICOC process has generated to set up a peer-to-peer support mechanism for FCAS governments looking to better regulate the activities of PSCs and civil society groups (both national and international) involved in their oversight and accountability.

- Create better links among regulatory frameworks covering markets in both equipment and services. This can be done by revisiting the drafting, adoption and implementation of arms embargoes to make them more effective at preventing transfers of military and security equipment and to clarify how they apply to the operations of PSCs delivering different services within their jurisdiction (i.e. when PSCs provide armed protection services or logistical support to peacekeeping operations)

- Agree strict controls on the use, carriage and disposal of weapons and ammunition by PSCs, including when they are concluding their activities in a particular location or context, particularly when operating in FCAS.

\subsection{Entry point II: Regulating military and security assistance at both source and destination}

Relying only on regulation at source (in the state that is exporting weapons or is the home of a PMSC) or at destination (where enforcement capacity is weak) is not enough to ensure that mil/sec assistance plays a positive role in addressing conflict and fragility. It may be necessary to explore the double regulation of $\mathrm{mil} / \mathrm{sec}$ assistance, holding those involved in the supply of mil/sec goods and services accountable at both source and destination. This might include:

- Exploring the legal, political and practical implications of double regulation, drawing on experience from other fields.

- Redoubling efforts to eliminate discrepancies and loopholes between and within national legislations and regulatory regimes.

- Supporting the technical development and oversight of national controls (potentially modelled on international standards) to ensure they are effective. 
- Supporting efforts to ensure that parliament, local authorities and the public in FCAS have an appropriate role in providing oversight and accountability to the security sector, whether public or private.

\subsection{Entry point III: Linking access to markets in military and security assistance to good governance}

To achieve this, INCAF members could:

- Establish a list of fragile countries of concern, outlining why the transfer of particular forms of mil/sec assistance to these countries might negatively affect conflict and fragility. This which would enable harmonised decision making about whether to authorise specific transfers to these countries.

- Take into account the quality of governance as a risk factor when deciding if and how to provide military and security assistance

- Operate a policy of "presumption of denial" for arms and security transfers, whereby permission for a transfer will be withheld unless (1) there is a clearly identified legitimate security need; and (2) all parties are confident the recipient or the provider of the services will be held accountable and will meet certain agreed standards. These could include the democratic oversight of the security services, suitable (parliamentary/public) oversight of government defence and security procurement and robust national legislation to regulate private security providers.

- Link this approach to broader governance issues and wider development frameworks such as the New Deal for International Engagement in Fragile States (International Dialogue on Peacebuilding and Statebuilding, 2011). Thus potential recipients and users of military and security assistance would need to demonstrate progress on governance issues, for example by improving against the World Bank's World Governance Indicators (particularly anti-corruption measures) ${ }^{2}$ and/or the New Deal's peacebuilding and statebuilding goals, in addition to good governance of the security sector.

- Ensure the New Deal and the new development framework following the end of Millennium Development Goal period set appropriate targets and indicators for public security to help assess transfers of arms and security equipment against security governance criteria.

\subsection{Entry point IV: Developing guidelines for PMSCs for supporting security and justice programming}

It has become increasingly common for donor governments to use external contractors to deliver programming relating to security and justice. Currently, there is little clear guidance and/or criteria to help donors decide when and how to contract such programmes. INCAF members could develop such guidelines and promote them with the donor community. Such guidance should include:

- $\quad$ policy guidance making clear linkages between security and justice programming and other key policy commitments around aid effectiveness, peacebuilding and statebuilding and gender;

- criteria for selecting contractors, including evaluation of past performance, appropriateness of business models, consistency with other key policies (as above);

- criteria for contractor management and oversight, including monitoring and responding to changing security and political contexts, liaising with host country and other donors, adapting security and justice contracts as appropriate;

\footnotetext{
${ }^{2}$ The World Governance Indicators are a set of aggregated and individual indicators that rate the quality of governance in each country according to six key dimensions: voice and accountability; political stability and absence of violence; government effectiveness; regulatory quality; rule of law; and control of corruption. They are based on a wide range of expert and stakeholder views on governance in each country (World Bank, 2012).
} 
- regular contractor performance reviews that go beyond delivery of programme objectives and look at wider issues of consistency with above criteria, behaviour of personnel, etc.;

- details on how to ensure local ownership across the life of the programme, from initial decisions about bid selection right through to end-of-programme evaluation. 


\section{Conclusions and areas for further research}

National, regional and international regulatory frameworks have largely failed to keep pace with the rapid developments in military and security markets in recent years, deepening the risks that mil/sec assistance will be used in ways that have deleterious effects on conflict and fragility. There is thus a need to redouble efforts to strengthen, harmonise and enforce regulation in this field. However, a regulatory system that assumes that all states have equal enforcement capacity is flawed, given the weakness of regulatory regimes in most FCAS and the strong financial and political advantages that can often be gained by overriding such controls. This suggests a need to explore double regulation to ensure that $\mathrm{mil} / \mathrm{sec}$ assistance is better controlled at both source and destination, as well as a number of other initiatives to strengthen regulation and the links between development, governance and the control of military and security markets. Implementing some of the entry points suggested above warrant further research and evidence. These are discussed below.

\subsection{How can embargoes/sanctions regimes be more effective?}

Between the creation of the UN and the conclusion of the Cold War the UN Security Council has only restricted arms and security transfers twice. ${ }^{3}$ However, the use of sanctions regimes increased exponentially in the 1990s as a reaction to the proliferation of devastating armed conflicts, in particular on the African continent. A review of the practical challenges to implementation, monitoring and management of embargoes and other restrictive measures was conducted in the mid-1990s and was followed by a series of informal working groups, UNSC and UN General Assembly resolutions, reports by the UN Secretary General, the establishment of sanctions monitoring groups and ultimately UN Sanctions Committees and Panels of Experts. Nevertheless, the implementation of many sanctions regimes continues to be problematic, partial and limited in impact, as demonstrated by an "unofficial" report by three former members of the Sudan embargo panel which outlines numerous weaknesses in the implementation of that embargo (Gramizzi et al., 2011). The reasons why sanctions regimes mainly fail to change behaviour could do with further research and analysis. This would help ensure that future sanctions regimes are more effective.

\subsection{How can the regulation of military and security assistance be improved in areas of weak or disputed governance?}

The regulation of military and security assistance, and in particular the transfer of weapons and related equipment, generally assumes some element of jurisdiction and ownership. However, military and security assistance sometimes takes place in areas where jurisdiction is unclear or disputed, such as to peacekeeping operations in disputed regions or ungoverned spaces. While this may not be a problem in itself, when this equipment is given to third parties upon completion of operations or simply left in theatre, this can raise concerns over proliferation. Further research is needed into whether and how this affects conflict, fragility and prospects for long-term peace and security.

\subsection{What best practice in import controls can we apply?}

Effective arms transfer controls should regulate all relevant activities - including export, import, re-export, transit/transhipment, temporary transfers, sales, loans, gifts, leases - and transactions involving other relevant parties (such as brokering, transport and financial services). Controls must be applied consistently in order to avoid loopholes being exploited by unscrupulous entities. Import controls are a particularly important part of efforts to prevent the unauthorised transfer of weapons to non-state actors and to provide an element of accountability by the recipient state. Where import controls are absent or

\footnotetext{
${ }^{3}$ These sanctions regimes targeted Rhodesia (Resolution 253, 1968) and South Africa (Resolution 421, 1977). During the Cold War period, Permanent Members extensively used their right of veto to avoid measures being imposed on their allies.
} 
ineffective the task of preventing and combating illicit trafficking is made extremely difficult. However, information and research on best practice in import control is scant and further research could help inform and shape more effective international, regional and national policy responses.

\subsection{How can we trace illicit conflict ammunition?}

Illicit conflict ammunition ${ }^{4}$ presents clear challenges to international peace and security. It sustains armed conflicts after the imposition of embargoes and facilitates violations of international humanitarian and human rights law committed in the context of armed conflicts. There is a growing international recognition of the challenges posed by illicit conflict ammunition as well as of the potential benefits of tracing such ammunition. More can and should be done to prevent the illicit supply of ammunition to groups engaged in armed conflict. Ammunition tracing is a key tool to identify flows of illicit conflict ammunition and identify diversion points, but further targeted research is needed to provide a sufficiently robust evidence base to spur international action.

\subsection{Are current guidelines on the use of private security providers in humanitarian and development work effective?}

As noted above, guidance has recently been developed by the EISF for humanitarian agencies that may seek to involve private security providers in security arrangements. It would be helpful to assess the impact of this guidance after it has been in operation for two or three years to identify whether security provision has improved in quality and effectiveness and whether this has had a positive effect on peace and conflict dynamics in FCAS. More generally, it would be helpful to look more broadly at the impact of all relevant guidelines for PMSC engagement in FCAS through the same lens.

\footnotetext{
${ }^{4}$ Such as ammunition that is transferred in violation of mandatory UN Security Council embargoes and thereby of international law, and that is used by groups engaged in armed conflicts in violation of international humanitarian and human rights law.
} 


\section{Bibliography}

Abrahamsen, R. and M. Williams (2008) "Beyond the Privatised Military", Human Security Bulletin, 6(3).

Amnesty International (2012), Sudan: No End to Violence in Darfur, Amnesty International, London, www. amnestyusa.org/sites/default/files/afr540072012en.pdf.

Azazi, O. A. (2012), "Combating a Common Terrorist Threat”, Washington Times, 4 January 2012.

Bennett, J. R. (2009), “Outsourcing Africa”, ISN Security Watch, 12 October 2009.

Bennett, J. R. (2011), “Contractors to the Congo", ISN Security Watch, 1 December 2011.

BMP4 (2011), BMP4: Best Management Practices for Protection against Somalia Based Piracy: Suggested planning and operational practices for ship operators and masters of ships transiting the high risk area, Witherby, Edinburgh.

Boone, J. (2010a), "Foreign Contractors Hired Afghan Dancing Boys, WikiLeaks Cable Reveals", The Guardian, 2 December 2010.

Boone, J. (2010b), "Karzai to Scrap Booming Private Security Industry in Afghanistan", The Guardian, 16 August 2010.

Brooks, D. (2012), "(in)Stability Operations”, Journal of International Peace Operations, 7(5) March-April, 2012.

Brooks, D. and S. L. Rathgeber (2008), "The Industry Role in Regulating Private Security Companies", Human Security Bulletin, 6(3).

Brzoska, M. (2006), “Trends in Global Military and Civilian Research and Development and their Changing Interface," Proceedings of the International Seminar on Defence Finance and Economics, New Delhi, November 2006, available at www.ifsh.de/pdf/aktuelles/india_brzoska.pdf.

Cockayne, J., et al. (2009), Beyond Market Forces: Regulating the Global Security Industry, International Peace Institute, New York.

Costello, M. (2011), "London Insurers' Private Fleet to Fight Somali Pirates", The Times, 18 February 2011.

Cullen, P. (2008), “Africa: Fisheries Under PSC Watch”, ISN Security Watch, 11 November 2008.

Daly, J.C.K. (2008), "The Deadly Convenience of Victor Bout", ISN Security Watch, 24 June 2008, http://isn.ethz.ch/isn/Security-Watch/Articles/Detail/?Ing=en\&id=88499.

Dasgupta, S. (2008), "The Public Domain Question in Non-State Armed Groups Hiring PMCs", Human Security Bulletin, 6(3).

Defence Industry Daily (2005), “ITAR Fallout: Britain to Pull Out of F-35 JSF Program?", Defence Industry Daily, 7 December 2005, available at www.defenseindustrydaily.com/itar-fallout-britain-to-pull-out-off35-jsf-program-01587/. 
DFID (Department for International Development) (2009), Eliminating World Poverty, Building our Common Future, DFID, London.

Economist, The (2010), "A Mercenary Solution to Somali Piracy", The Economist, 20 December 2010.

ECOWAS (Economic Community of West African States) (2006), ECOWAS Convention on Small Arms and Light Weapons, Their Ammunition and Other Related Material, ECOWAS, available at www.unidir.org/pdf/articles/pdf-art2836.pdf.

EISF (European Interagency Security Forum) (2011), Engaging Private Security Providers: A Guideline for Non-Governmental Organisations, EISF Briefing Paper, EISF.

EU (European Union) (1998), European Union Code of Conduct on Arms Exports, EU, Brussels, www.consilium. europa.eu/uedocs/cmsUpload/08675r2en8.pdf.

EU (2008), "Acts Adopted Under Title V of the EU Treaty: Council Common Position 2008/944/CFSP of 8 December 2008 Defining Common Rules Governing Control of Exports of Military Technology and Equipment", Official Journal of the European Union, L 335/99, http://eurlex.europa.eu/LexUriServ/LexUriServ.do?uri=OJ:L:2008:335:0099:0103:EN:PDF.

EU (2009a), "Directive 2009/43/EC of the European Parliament and of the Council, Simplifying Terms and Conditions of Transfers of Defence-Related Products within the Community", Official Journal of the European Union, L146/1-36.

EU (2009b), User's Guide to Council Common Position 2008/944/CFSP Defining Common Rules Governing the Control of Exports of Military Technology and Equipment, EU, Brussels, http://register.consilium.europa.eu/pdf/en/09/st09/st09241.en09.pdf.

Foaleng, M. (2007) "Private Military and Security Companies and the Nexus between Natural Resources and Civil Wars in Africa", in S. Gumedze (ed.), Private Security in Africa: Manifestations, Challenges and Regulation, ISS Monograph Series, No 139, Institute for Security Studies.

Gettleman, J., M. Mazzetti and E. Schmitt (2011), "US Relies on Contractors in Somalia Conflict", New York Times, 10 August 2011.

Gichanga, M. (2010) Fusing Privatisation of Security with Peace and Security Initiatives, ISS Paper 219, Institute for Security Studies.

Gichanga, M., M. Roberts and S. Gumedze (2010), Conference Report: The Involvement of the Private Security Sector in Peacekeeping Missions, Institute for Security Studies, Nairobi, Kenya.

Gramizzi, C., M. Lewis and J. Tubiana (2011), Letter Dated 24 January 2011 from Former Members of the Panel of Experts on the Sudan Established Pursuant to Resolution 1591 (2005) and Renewed Pursuant to Resolution 1945 (2010) Addressed to the Chairman of the Security Council Committee Established Pursuant to Resolution 1591 (2005) Concerning the Sudan, available at http://dl.dropbox.com/u/72848070/Report\%20of\%20former\%20members\%20of\%20the\%20UNSC\% 20Panel\%20of\%20Experts\%20on\%20the\%20Sudan\%20January\%202012.pdf (accessed 1 June, 2012).

Gumedze, S. (ed.) (2007), Private Security in Africa: Manifestations, Challenges and Regulation, ISS Monograph Series, No 139, Institute for Security Studies. 
Hoffman, C. (2005), "Building your Own Airforce, One MIG at a Time", Wired, October 2005, www.wired.com/wired/archive/13.10/kirlin.html.

Human Rights First (2008), Private Security Contractors at War: Ending the Culture of Impunity, Human Rights First, New York.

ICOC (International Code of Conduct for Private Security Service Providers) (2010), International Code of Conduct for Private Security Service Providers, ICOC, Berne.

ICOC (2012), "The International Code of Conduct for Private Security Service Providers Signatory Companies", ICOC Website, www.icoc-psp.org/uploads/Signatory_Companies_-_April_2012__Composite_List.pdf.

ICRC (International Committee of the Red Cross) (n.d.) "State Parties / Signatories to the International Convention Against the Recruitment, Use, Financing and Training of Mercenaries, 4 December 1989", ICRC Website, www.icrc.org/ihl.nsf/WebSign?ReadForm\&id=530\&ps=P, accessed 10 September 2012.

IMO (International Maritime Organization), (2011), Revised Interim Guidance to Shipowners, Ship Operators and Shipmasters on the Use of Privately Contracted Armed Security Personnel on Board Ships in the High Risk Area, MSC.1/Circ. 1405/Rev.1 16 September 2011, IMO, London.

Ince \& Co. (2011), Piracy - Issues Arising from the Use of Armed Guards, Ince \& Co., London.

Ingram, P. and I. Davis (2001), The Subsidy Trap: British Government Financial Support for Arms Exports and the Defence Industry, Oxford Research Group/Saferworld.

InterManager (2011a), "UK U-Turn on Armed Guards Lifts Threat of Prosecution", 13 October 2011, www.intermanager.org/2011/10/uk-u-turn-on-armed-guards-lifts-threat-of-prosecution/, accessed 10 September 2012.

InterManager (2011b), "Owners Gun for Guards in Indian Ocean", 21 October 2011, www.intermanager.org/2011/10/owners-gun-for-guards-in-indian-ocean/, accessed 10 September 2012.

International Dialogue on Peacebuilding and Statebuilding (2011), A New Deal for Engagement in Fragile States emanating from the Fourth High Level Forum on Aid Effectiveness in Busan, International Dialogue on Peacebuilding and Statebuilding, OECD, Paris.

ISOA (International Stability Operations Association) (2011) ISOA Code of Conduct, Version 13.1, 20 October 2011, ISOA website, www.stability-operations.org/index.php.

ISOA (2012) "International Stability Operations Association: IPOA's new name", ISOA press release, available at www.prnewswire.com/news-releases/international-stability-operations-associationipoas-new-name-105686208.html (accessed 22 February 2012).

Ivzhenko, T. (2008), “Army Clearance Sale”, Nezavisimaya Gazeta, 10 November 2008.

Joras, U. and A. Schuster (eds.) (2008), Private Security Companies and Local Populations: An Exploratory Study of Afghanistan and Angola, Swisspeace, Bern.

Lewis, M. (2012), "Guns and Bread”, New Internationalist, January / February 2012. 
Lowe, M. (2012), "Floating Armouries", Maritime Security Review, 16 May 2012, www.marsecreview.com/2012/03/floating-armouries/.

Maritime Security Asia (2011), "Private Navy Fights Somali Piracy", Maritime Security Asia, 13 November 2011.

Montague, D. (2002), "The Business of War and Prospects for Peace in Sierra Leone", The Brown Journal of World Affairs, 9(1) Spring 2002, www.worldpolicy.newschool.edu/projects/arms/news/brown.pdf.

Montreux Document (2008), Montreux Document on Pertinent International Legal Obligations and Good Practices for States related to Operations of Private Military and Security Companies during Armed Conflict, 17 September 2008, available at www.eda.admin.ch/psc, accessed 10 September 2012.

Motzouris, M. (2011), Conference Report on the Involvement of the Private Security Sector in Humanitarian Assistance Operations in Africa, Institute for Security Studies, Nairobi.

Nairobi Protocol (2004), The Nairobi Protocol for the Prevention, Control and Reduction of Small Arms and Light Weapons in the Great Lakes Region and the Horn of Africa, Signed in Nairobi, 21 April, 2004, available at www.recsasec.org/pdf/Nairobi Protocol.pdf.

Ndlovu-Gatsheni, Sabelo J. (2007), "Weak States and the Growth of the Private Security Sector in Africa: Whither the African State?", in S. Gumedze (ed.), Private Security in Africa: Manifestations, Challenges and Regulation, ISS Monograph Series, No 139, Institute for Security Studies, Nairobi.

OAS (Organization of American States) (1997), Inter-American Convention Against Illicit Manufacturing of and Trafficking in Firearms, Ammunition, Explosives and Other Related Materials, OAS, Washington DC, available at www.state.gov/p/wha/rls/49907.htm.

OCCRP (Organised Crime and Corruption Reporting Project) (2010), "Security Chaos", OCCRP website, www.reportingproject.net/security.

OECD (Organisation for Economic Co-operation and Development) (2011), Supporting Statebuilding in Situations of Conflict and Fragility, Policy Guidance, DAC Guidelines and Reference Series, OECD Publishing, Paris, http://dx.doi.org/10.1787/9789264074989-en.

Offenhauer, P. (2008), Israel's Technology Sector, Federal Research Division, Library of Congress, Washington, DC, www.dtic. mil/cgi-bin/GetTRDoc?AD=ADA513983.

OSCE (Organization for Security and Co-operation in Europe) (1993), Principles Governing Conventional Arms Transfers, OSCE, Vienna, www.osce.org/fsc/42313.

OSCE (2000), OSCE Document on Small Arms and Light Weapons, FSC.DOC/1/00/Rev.1, OSCE, Vienna, www.osce.org/fsc/20783.

OSCE (2004) "Decision No. 5/04: Standard Elements of End-User Certificate and Verification Procedures for SALW Exports", FSC Journal, No. 442, Agenda item 6, www.osce.org/fsc/16941.

Quinn, P. (2012), “U.S. Approves Egypt Military Aid Despite Rights Fears", Reuters, 23 March 2012, www.reuters.com/article/2012/03/23/us-egypt-usa-aid-idUSBRE82MOUG20120323. 
Renouf, J. S. (2007), Do Private Security Companies Have a Role in Ensuring the Security of Local Populations and Aid Workers? Lecture, $5^{\text {th }}$ Autumn Humanitarian University, Groupe URD, Provence, $\quad$ September 2007, available at www.securitymanagementinitiative.org/index.php?option=com_docman\&task=doc_details\&gid=47\&l ang=fr\&/temid=28, accessed 10 September 2012.

Richards, A. and H. Smith (2007), Addressing the Role of Private Security Companies within Security Sector Reform Programmes, Saferworld, London.

SADC (Southern African Development Community) (2001), Protocol on Control of Firearms, Ammunition and Other Related Materials, SADC, Gaborone, www.sadc.int/index/browse/page/125.

Saferworld (2002) Arms Production, Exports and Decision-Making in Central and Eastern Europe, Saferworld, London, www.saferworld.org.uk/downloads/pubdocs/Beast\%20Bulgaria.pdf.

Saferworld (2007), Evaluation of the Sarajevo Process, internal document made available to authors, Saferworld, London.

Saferworld (2011), The Securitisation of Aid? Reclaiming Security to Meet Poor People's Needs, Saferworld Briefing, Saferworld, London.

SMI (Security Management Initiative) (2009), Private Military and Security Companies and Humanitarian Action, SMI Professional Development Brief 1, SMI, Geneva.

SEESAC (South Eastern Europe Clearinghouse for the Control of Small Arms and Light Weapons) (2005), SALW and Private Security Companies in South Eastern Europe: A Cause or Effect of Insecurity? SEESAC Publications, Belgrade.

SEESAC (2006a), The 'Sarajevo Code of Conduct' for Private Security Companies, SEESAC, Belgrade.

SEESAC (2006b), The 'Sarajevo Client Guidelines' for the Procurement of Private Security Companies, SEESAC, Belgrade.

SEESAC (n.d.), The SEESAC Regional Micro-Disarmament Standards and Guidelines (RMDS/G), SEESAC website, www.seesac.org/resources/standards-rmdsg/1/.

Sherman, J. and V. di Domenico (2009), The Public Cost of Private Security in Afghanistan, Briefing Paper, Centre on International Cooperation, New York University, New York.

Sierra Leone Truth \& Reconciliation Commission (2004), Witness to Truth: Report of the Sierra Leone Truth \& Reconciliation Commission, Vol. 2, Truth \& Reconciliation Commission, Accra, Ghana, www.sierra-leone.org/Other-Conflict/TRCVolume2.pdf.

Singer, P. (2007), Can't Win With ‘Em, Can't Go To War Without 'Em: Private Military Contractors and Counterinsurgency, Brookings Foreign Policy Paper Number 4, Brookings Institution, Washington DC.

SIPRI (Stockholm International Peace Research Institute) (2011), SIPRI Yearbook 2011: Armaments, Disarmament and International Security, Oxford University Press, Oxford.

Small Arms Survey (2003), Small Arms Survey 2003: Development Denied, Small Arms Survey, Geneva, www.smallarmssurvey.org/publications/by-type/yearbook/small-arms-survey-2003.html. 
Smith, General Sir R. (2005), The Utility of Force: The Art of War in the Modern World, Allen Lane, London.

Spearin, C. (2008), "What Manley Missed: The Human Security Implications of Private Security in Afghanistan", Human Security Bulletin, 6(3).

Speers Mears, E. (2009), Private Military and Security Companies and Humanitarian Action, Security Management Initiative, Geneva.

Stoddard, A., A. Harmer and V. di Domenico (2008), The Use of Private Security Providers and Services in Humanitarian Operations, HPG Report 27, Humanitarian Policy Group, ODI (Overseas Development Institute), London.

Stowsky, J. (1991), "From Spin-off to Spin-on: Redefining the military's role in technology development", Working Paper 50, Berkeley Roundtable on the International Economy, http://escholarship.org/uc/item/0tf8v3c7\#page-1.

Transparency International (2011), Strategic Export Controls: Evidence submitted by Transparency International to the UK Quadripartite Select Committee, February 2011. www.publications.parliament.uk/pa/cm201011/cmselect/cmquad/writev/arms/m4.htm

UK Government (2010), Securing Britain in an Age of Uncertainty: The Strategic Defence and Security Review, UK Government, London.

UK Government (2011a), Building Stability Overseas Strategy, UK Government, London, www.fco.gov.uk/resources/en/pdf/publications/annual-reports/bsos-july-11

UK Government (2011b), Foreign and Commonwealth Office. Business Plan 2011-2015, Foreign and Commonwealth Office, London.

UN (United Nations) (2001), Programme of Action to Prevent, Combat and Eradicate the Illicit Trade in Small Arms and Light Weapons in All its Aspects, UN, New York, www.poaiss.org/poa/poahtml.aspx

UN (2005), International Instrument to Enable States to Identify and Trace, in a Timely and Reliable Manner, Illicit Small Arms and Light Weapons (International Tracing Instrument), UN Programme of Action Implementation Support System, UN, New York, www.poaiss.org/InternationalTracing/ITI_English.pdf.

UN (2010), Central African Convention for the Control of Small Arms and Light Weapons, Their Ammunition and All Parts and Components that Can be Used for Their Manufacture, Repair and Assembly, UN, New York, http://treaties.un.org/doc/source/signature/2010/XXVI-7.pdf.

UN (2012), What is Peacekeeping? UN website, www.un.org/en/peacekeeping/operations/peacekeeping.shtml, accessed 12 February 2012).

UN General Assembly (1989), International Convention Against the Recruitment, Use, Financing and Training of Mercenaries, A/RES/43/34, 72nd Plenary Meeting, 4 December 1989, UN, New York, www.un.org/documents/ga/res/44/a44r034.htm.

UN General Assembly (1996), "Guidelines for International Arms Transfers in the Context of General Assembly Resolution 46/36 $\mathrm{H}$ of 6 December 1991" in Review of the Implementation of the 
Recommendations and Decisions Adopted by the General Assembly at its Tenth Special Session: Report of the Disarmament Commission, UN, New York, www.un.org/Depts/ddar/discomm/2102.htm\#tn.

UN General Assembly (2001), Protocol Against the Illicit Manufacturing of and Trafficking in Firearms, Their Parts and Components and Ammunition, Supplementing the United Nations Convention against Transnational Organized Crime, Resolution Adopted by the General Assembly 55/255, 8 June 2001, UN, New York, www.unodc.org/pdf/crime/a_res_55/255e.pdf.

UN General Assembly (2007), Report of the Group of Governmental Experts established pursuant to General Assembly Resolution 60/81 to Consider Further Steps to Enhance International Cooperation in Preventing, Combating and Eradicating Illicit Brokering in Small Arms and Light Weapons, A/62/163, UN, New York, www.poa-iss.org/BrokeringControls/English_N0744232.pdf.

UN Human Rights Council (2010a), Report of the Working Group on the Use of Mercenaries as a Means of Violating Human Rights and Impeding the Exercise of the Right of Peoples to Self-Determination - Mission to the United States of America, UN, New York.

UN Human Rights Council (2010b), Report of the Working Group on the Use of Mercenaries as a Means of Violating Human Rights and Impeding the Exercise of the Right of Peoples to Self-Determination - Mission to Afghanistan, UN, New York.

UN Human Rights Council (2011a), Report of the Working Group on the Use of Mercenaries as a Means of Violating Human Rights and Impeding the Exercise of the Right of Peoples to Self-Determination - Mission to South Africa, UN, New York

UN Human Rights Council (2011b), Report of the Working Group on the Use of Mercenaries as a Means of Violating Human Rights and Impeding the Exercise of the Right of Peoples to Self-Determination - Mission to Iraq, UN, New York.

UN Register of Conventional Arms (n.d.), The Global Reported Arms Trade: South Africa, All Years, UN Register of Conventional Arms website, ww.unregister.org/HeavyWeapons/index.aspx?Col=ZA\&year=0\&Cat=0.

UN Security Council (1991), "Guidelines for Conventional Arms Transfers", Meeting of the Five on Arms Transfers and Non-Proliferation, London, 17-18 October, 1991, available at www.un.org/disarmament/convarms/ATTPrepCom/Background documents/1991 CD1113 - P5 guidelines - E.pdf.

UN Security Council (2000), Report of the Panel of Experts on Violations of Security Council Sanctions Against UNITA, UN, New York, www.securitycouncilreport.org/atf/cf/\%7B65BFCF9B-6D27-4E9C8CD3-CF6E4FF96FF9\%7D/Sanc\%20S2000\%20203.pdf.

UN Security Council (2004), Resolution 1540, UN, New York, available at www.vertic.org/media/assets/nim_docs/Treaty/resolutions/S_RES_1540_text_English.pdf.

UN Security Council (2008), Report of the Monitoring Group on Somalia Pursuant to Security Council Resolution 1811, UN, New York, www.un.org/ga/search/view_doc.asp?symbol=S/2008/769.

UN Security Council (2011), Report of the Monitoring Group on Somalia and Eritrea Pursuant to Security Council Resolution 1916 (2010), UN, New York. 
UNODA (United Nations Office for Disarmament Affairs) (2011), International Ammunition Technical Guidelines, UNODA, New York, www.un.org/disarmament/convarms/Ammunition/IATG/.

UNODA (n.d. a), UN Register of Conventional Arms, UNODA website, www.un.org/disarmament/convarms/Register/.

UNODA (n.d. b), Military Spending, UNODA website, www.un.org/disarmament/convarms/Milex.

Vuijlsteke, M. and P. Stroobants (eds.) (2006), "Private Military / Security Companies Operating in Situations of Armed Conflict", Proceedings of the $7^{\text {th }}$ Bruges Colloquium, 19-20 October, 2006, Bruges.

War on Want (2006), Corporate Mercenaries: The Threat of Private Military and Security Companies, War on Want, London.

Wassenaar Arrangement (1995), Wassenaar Arrangement on Export Controls for Conventional Arms and Dual-Use Goods and Technologies Final Declaration, Wassenaar Arrangement, www.wassenaar.org/publicdocuments/declaration.html.

Wassenaar Arrangement (2007), Best Practices to Prevent Destabilising Transfers of Small Arms and Light Weapons (SALW) through Air Transport, Wassenaar Arrangement, www.wassenaar.org/publicdocuments/2007/docs/Best_Practices_to_Prevent_Destabilising_Transfe rs_of.pdf

Wiese Bockmann, M. (2011), "Somalia Piracy Spurs Private Navy to Start Within Five Months", Bloomberg, 8 November 2011.

Wolf, J. (2009), "U.S. to withhold F-35 fighter software code", Reuters, 24 November 2009, www.reuters.com/article/2009/11/25/us-lockheed-fighter-exclusive-idUSTRE5AO01F20091125.

World Bank (2011), World Development Report 2011: Conflict, Security and Development, World Bank, Washington DC.

World Bank (2012), World Governance Indicators, available at http://info.worldbank.org/governance/wgi/index.asp, accessed 11 September 2012. 
